\title{
耳後部通電の作用部位に関する研究
}

——聴性脳幹反応の変化並びに病理組織学的検索——

$$
\text { 日吉正明 }
$$

\section{Effect of the Retroauricular Galvanic Stimulation on the} Brainstem of Cats

-from the standpoint of ABR findings and histopathological changes-

\author{
Masaaki Hiyoshi \\ (Yamaguchi University)
}

The electro-physiological and morphological changes in the brainstem of the cats occurred after galvanic stimulation through the retro-auricular electrode. The resulting changes were topographically studied.

Otoneurologically healthy 18 cats were divided into three groups: the control group, the group receiving $2 \mathrm{~mA}$ of direct current for 20 minutes (" $2 \mathrm{~mA}$ group") and the group receiving $10 \mathrm{~mA}$ for $20 \mathrm{~min}$. ("10 mA group"). Auditory brainstem response (ABR) was measured in all cats at several designated time periods pre- and post-stimulation under light general anesthesia. The latency and amplitude of ABR waves I to V were calculated and compared. After the completion of ABR measurement, the animals'brain tissues were extracted according to the standardized vital perfusion-fixarion method. The cortical area, where the indifferent electrode was embedded, and the brainstem were dissected for histopathological specimens. Specimens were stained using HE stains, Nissl, Klüver \& Barrera and Bodian staining methods.

The findings were as follows:

1. Eye deviation induced by galvanic stimulation was obseved in all animals in the " $2 \mathrm{~mA}$ group" and the "10 $\mathrm{mA}$ group".

2. Changes of latency and amplitude of the I, III, and V waves on the right side (the stimulated side) were significant in the " $10 \mathrm{~mA}$ group " compared to the control group. Similarly, the changes of latency of the I and V waves on the left side (non-stimulated side) differed significantly between the " $10 \mathrm{~mA}$ group" and the "control group".

3. Disappearance of the II, III, IV and V waves on the stimulated side and of the II, III, and V waves on the non-stimulated side were observed in the " $10 \mathrm{~mA}$ group ". Only the V wave on both sides of the " $2 \mathrm{~mA}$ group " disappeared.

4. Histopathological survey of the brainstem of the " $10 \mathrm{~mA}$ group " revealed that changes occurred in the ipsilateral vestibular nuclei, cochlear nuclei, lateral lemniscus, nucleus of the facial nerve, nucleus of the abducent nerve and facial nerve bundle; and also in the bilateral reticular formation, medial longitudinal fasciculus, superior olibary nucleus and commissure of inferior colliculus. 


\section{I 緒言 \\ I 予備実験 \\ 1 通電に関して \\ 2 ABRに関して \\ III方法と対象 \\ 1 対象 \\ 2 使用器機 \\ 1) 通電刺激 \\ 2) A B R 計測 \\ 3 ネ汇電極の作成と設置 \\ 4 通電刺激並に A B R 計測 \\ IV 成績}

1 電気性眼球偏位の成績

1) 対照群

2) $10 \mathrm{~mA}$ 群

3) $2 \mathrm{~mA}$ 群

4) 小括

\section{目次}

2 A B Rの成績

1) 対照群

2) $10 \mathrm{~mA}$ 群

3) $2 \mathrm{~m} \mathrm{~A}$ 群

4) 小括

3 病理組織学的検䇣の成績

1) 対照群

2) $10 \mathrm{~mA}$ 群

3) $2 \mathrm{~mA}$ 群

4) 小括

$\mathrm{V}$ 考案

V 結論

謝辞

参考文献

\section{緒}

言

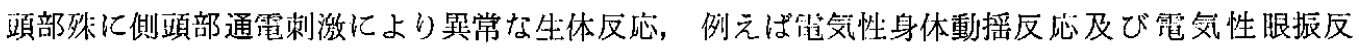
応, が誘発されることは，1792年 Volta が䘽祭し，さらに自らの頭部に通電して得られるめまい感 を報告したてとに始まる．更にPurkinje(1820) 壮平衡譏能の異常について，そして Hitzig(1871)

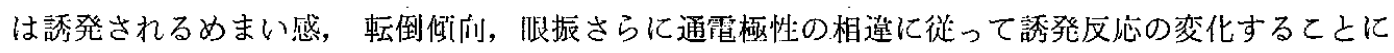

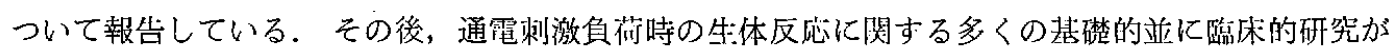
報告されている，乙れらの矿労の䍀床応用として, 所謂 Galvanic test が前庭機能検査法に加えら

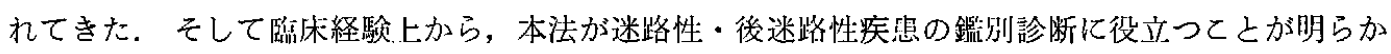
にされた.

しかし、な招 Galvanic test は負荇刺激の倠用部位, 誘発反応の発現機序について未だ解朋され ていない点がある.とくに，作用部仙については諸説がある．それらについて，概説すると：

1 ) Endorgan 説; Breuer (1889) は八トを用い, 三半規管を佩々に雷気刺激した綃果, 刺激部 位は endorgan であろうと紝論した. Brüning (1911) は Kataphorese 説をとなえ，通霍により 内リンパに Kataphorese が抢こりクプラを制激し反射が起とると考えた.

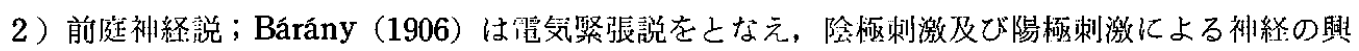

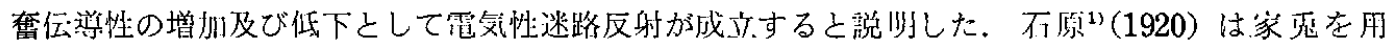

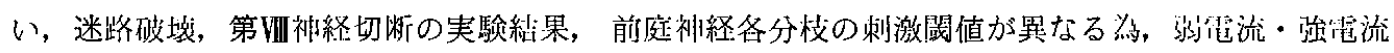

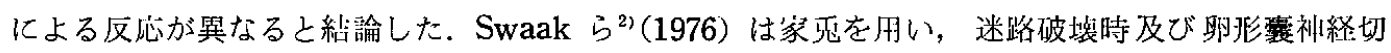
断時の Torsion-swing stimulation に対する反忘を检唁した絬果，Bárány の説を支持した。

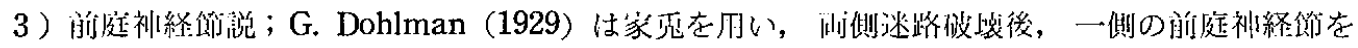

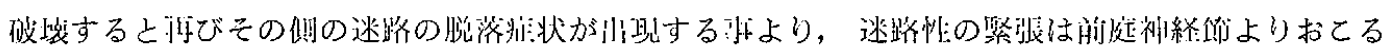

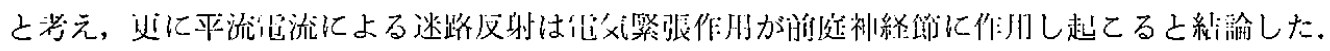




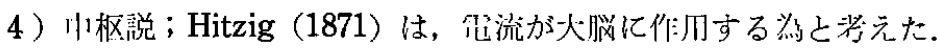

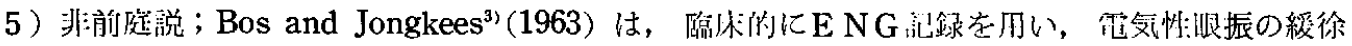

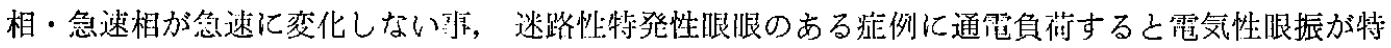
発性眼振の緩徐相に superimpose する事, さらに温度腿振と電気性眼振を同時に負荷すると電気 性眼振が温度眼振の緩徐相に superimpose する事より，非前庭系であると結諭した.

一方, 著者の研究公においては, 増田 ${ }^{4}$ (1960) が, 臨床的に, 書字検査, 足踏み検査及び Mann 検査時に通電刺激を負荷し, 前庭脊䯣反応を指標とした Galvanic test を報告し, さらに関谷 ${ }^{5}$

（1965）が，電気性身体動摇反応の定量的検査法 Galvanic body-sway test（以下 GBSTと略）を

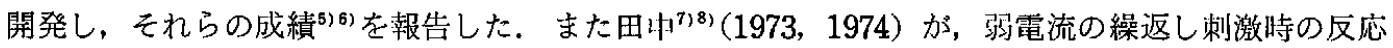

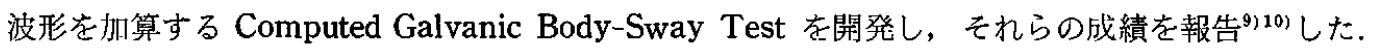
これらの臨床経験より，Galvanic test の刺激部位は，前庭神経・後迷路部分であろうと推定して いる. 特に, Vestibular neuronitis に代表される前庭神経疾患では，“slow and sluggish pattern” 即ち反応の避れを示す11)1213)14)が，一方 C-P angle tumor など中枢性と診断された症例では無反 応例が多い事を報告 ${ }^{15) 16) 17}$ した。

Pfaltz ら ${ }^{18)}$ (1968) は, Photoelectronystagmography（以下 PENG と峈）を用いて電気性眼振 を記録し, reversal phenomenon を指標とし, 籃床例 180 例即ち, 脳幹下部, 橋部, 中脳及び皮質 障害例を検討した。その結果より，Galvanic test は中枢前庭病変の局在診断、に重要な診断的価 值があろうと結論した。

以上，国内・国外の文献上，また著者の研劣室で報告してきたように，電気性身体動摇反応の作 用部位は前庭神経または前庭神経及び前庭神経節が考えられる。しかし，さらに通電刺激の作用は， 脳幹部におよび脳幹部での局在性が強く示唆される.

本研究では，比較的強い電流を耳後部・頭頂部間に通電することにより頭蓋内組織に機能的並に 器質的障㫪を起てさしめ検討すべく実験を試みた。指嘼は, 䨘気性眼球偏位, 恥性脳幹反応 (Auditory brainstem response 以下 ABR と略) 及び病理組織学的㭘索である. それらの結果と併せ て文献的考察を加え報告した。

\section{予 備 実 験}

\section{1 通電に関して}

本実験の実験条件設定のために以下の予蒈実 験を行った。 その大略を述べる，健康な成猫を 用いた。電極設置法は単耳単極法（unipolar test）とし，電極と雱極住置及び通霍電流量と 時間を決定した。

自作したネジ電極を用い，陰極は，解剖学上 右側頭骨乳突部三角とした。陽極の位置は，陰 極固定後電気性眼球偏位を指權として陽極を移 動し, 矢状縫合と冠状縫合の交叉部の尾側約 1 cmとした。

通電電流及び侍間決定の為に, $20 \mathrm{~mA} 20$ 分間 及び $10 \mathrm{~mA} 20$ 分間通雪を行った。結果, $20 \mathrm{~mA}$
20 分間通電例は 2 匹中 2 匹が通雱終了後間も なく死亡し， $10 \mathrm{~mA} 20$ 分間通電は 2 匹中 1 匹 が 3 洔間後に死亡した。 以上より $10 \mathrm{~mA} 20$ 分 間通霍を採用した。次に $1 \mathrm{~mA}$ A ら $5 \mathrm{~mA}$ の漸 増法による通電を行い，2匹中 2 匹ともに電気 性眼球偏位を解発する最低量として $2 \mathrm{~mA}$ を用 いることにした。

ネジ電極を頭蓋骨及び側頭,骨に刺入・固定し て検查を行った後開頭し, 電極先端の位置を検 索した。結果, 電極先端が頭蓋内に突出してい る部分では, 点状あるいは斑状のクモ膜下出血 を涩めるすのがあった，従って電極先端は，骨 内に設置するよう努力した。 

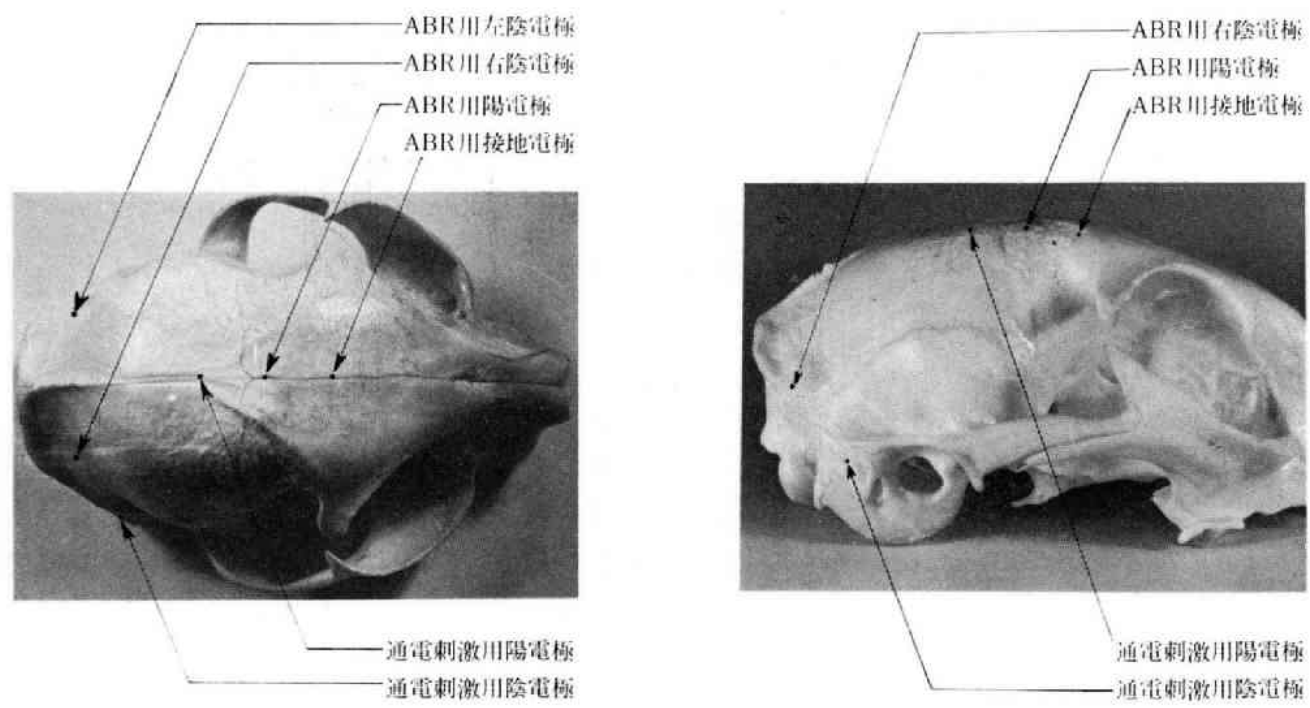

図）通電用並に A B R 用電極設置位置

\section{A B Rに関して}

猫A B R の記録の方法は, 教室の野口の方法 を改良し，用いた。即ちネジ電極設置法を用い た.これは電極の固定の容易さ及びA B R 波形 の定常性が期待できる. 予借実験の結果, 陽電 極は矢状縫合と冠状縫合の直前, 接地電極は陽 電極の鼻側 $1 \mathrm{~cm}$ 位置, 陰電極は左右ラムダ檤
合の直上で正中より約 $2 \mathrm{~cm}$ 横静脈洞を避けた 位置とした，図 1 に通電用並にA B R 用電極設 置位置を示す.

次にA B R 測定時間は, 通電後 24 時間 A B R の経時的変化を観察した結果より, 通電前, 通 電終了直後， $1 ， 2 ， 3 ， 12$ 及び 24 時間後の 7 時点とした。

\section{方法と対象}

\section{1 対象}

動物は神経耳科的にみて健康なる猫（子猫 6 匹，成猫12匹）を用いた。

\section{2 使用機器}

以下, 実験中諸計測は電気的にシールドされ た無響室内で行った.

1）通電刺激

電子管刺激装置 (日本光電製MS E - 3 R) 及び電圧計を用いた。

\section{2 ) A B R 测定}

シグナルプロセッサ（三栄測器製 $7 \mathrm{~S} 11$ ),

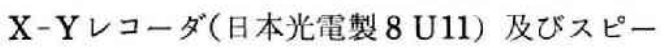
カーを用いた。 スピーカーは, 正面, 両耳入口 部より $30 \mathrm{~cm}$ 前方に置き, 最大音圧 $87 \mathrm{dBSPL}$, 刺 激音はクリック音, Low cut filter $80 \mathrm{~Hz}$, High cut filter $1.2 \mathrm{kHz}$, 加算回数 128 回, 解析時間 10 msec を用いた. Interval は 125,75 及び 25 msec を用い, さらに Interval $125 \mathrm{msec}$ は併 せて閾值まで测定した。 なお，音圧レベル（ $\mathrm{S}$ P L) は精密騒音計（Rion 製 NA-60）を用 い測定した，実験ブロックダイアグラムを図 2 に示す.

3 ネジ電極の作製と設置 ネジ電極 (真録製) は，エポキシ樹脂被覆加 工し絶縁性を確認の後, ネジ先端のみ被覆除去 し使用した。

ネンタブール $25 \mathrm{mg} / \mathrm{kg}$ 腹腔内投与後, 剃毛, 大伏在静脈に静脈カテーテル留置を行った，経 静脈的に適時追加投与し，至適麻酔レベルを維 持した，動物は猫固定器（教室の関谷が工夫, 


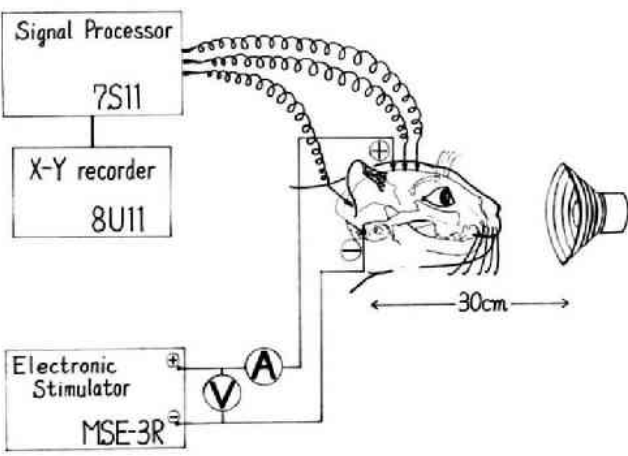

図 2 ブロックダイアグラム

自作したあのを改造）に固定し，保温した，術 前清潔手技を適用し, 諸手術を行った. 電極固 定部を十分に露出し, 正中線上, 矢状縫合と冠 状縫合の交叉部より $1 \mathrm{~cm}$ 尾側に通電用陽電極 を，その鼻側 $1 \mathrm{~cm}, 2 \mathrm{~cm}$ 位置に，それぞれ A B R 用陰電極及び接地電極を刺入し, さらに エポキシ樹脂固定した. 次に通電用㓌電極及び 右A B R 用陰電極を, それぞれ右側頭骨乳突三 角及びラムダ縫合直上の正中より約 $2 \mathrm{~cm}$ の位置 に固定した。最後に左A B R 用陰電極を同様の 方法により固定した。な招各電極間抵抗は固定 時に測定し， 4 ないし $7 \mathrm{~K} \Omega$ となるよう調整し た.

4 通電刺激並にA B R 計測

図3に示す実験プロトコールに従って実験を 行った. 電極固定24時間後, 再度電極の固定状 態, 電極間抵抗及び被動物の麻酔深度を確認 し, 動物固定の後, 実験を開始した. 図 4 に実 験室設置状態走示す. 定電流通電とし, $10 \mathrm{~mA}$ 及び $2 \mathrm{~mA} 20$ 分間通電（以下 $10 \mathrm{~mA}$ 群並に 2 $\mathrm{mA}$ 群之略）した。通電前後にわたり電気性眼 球偏位並に眼振を肉眼的に観察した。 A B R計 測在以下の各時点, 即ち通電前, 直後, 1 , $2 ， 3 ， 12$ 及び 24 時間後に行った。全経過中 Thermal data acquisition system（タカラ製 K700）を用い直腸温を測定し, 可及的に一定 体温の維持につとめた。 48時間後, 生体環流固 定を行った. phosphate buffered saline 注入 後, $2.5 \%$ glutaraldehyde, $0.4 \%$ paraformal- dehyde $0.1 \mathrm{M}$ リン酸綬衙液にて固定した。固 定終了後断頭・開頭し，10\%中性緩衝ホルマリ ンにて後周定した。主として脳幹部及び陽電極 直下の大脸をパラフィン包埋し, $10 \mu \mathrm{m}$ 厚の連 続切片を作製した。切片標本は，HE, Nissil, Klüver and Barrera 及び Bodian 法の各染色 をほどこし鏡検した。

$$
\text { 牧铞プロトコール }
$$

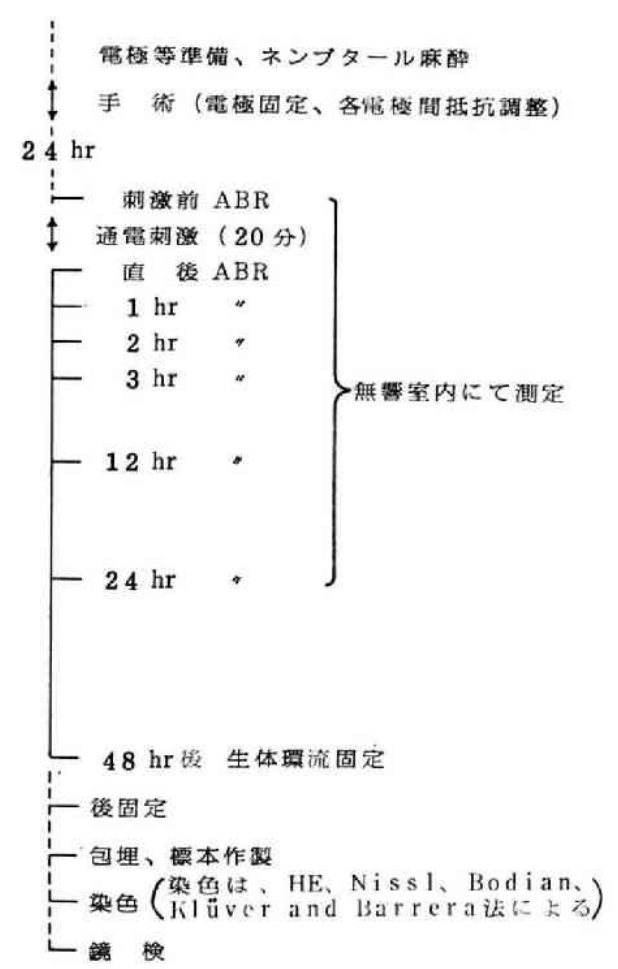

図 3

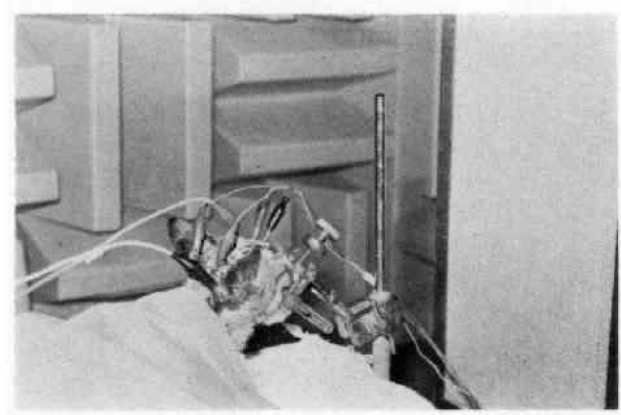

図 4 被動物, 電極固定並に実験室設置状態 
成

1 留気性服球偏仿の成績

結果を表 1 にまとめた

1 ) 対照群

対照群は, 全例, プロトコールに定めた洔間 内に眼球偏位は熟めない。

2) $10 \mathrm{~mA}$ 群

$10 \mathrm{~mA}$ 群は, 全例, 通電刺激に際し霄気性 服球偏位を認める。即ち, 通電時は 1 ないし 2 回, 通需中は 1 から 3 回, 及び遮電時は 1 ない し2回である。なお通霄終了後，24時間にわた

表 I 電気性眼球偏位並びに体重及び電極間抵抗成績

\begin{tabular}{|c|c|c|c|c|c|c|}
\hline \multirow[b]{2}{*}{$10 \mathrm{~m} \wedge$ 嗍 } & \multirow[b]{2}{*}{ 15: fi $(g)$} & \multirow[b]{2}{*}{ 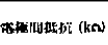 } & \multicolumn{4}{|c|}{ 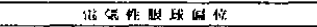 } \\
\hline & & & 吅粡 & 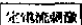 & off $w^{3}$ & 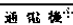 \\
\hline No. $201^{\star}$ & 1,800 & $5.1 \pm 0.1$ & 1 & 2 & 2 & 752 \\
\hline $202^{\star *}$ & 680 & $4.2 \pm 0.1$ & 2 & 3 & 2 & " \\
\hline 203 & 610 & $4.7 \pm 0.2$ & 1 & 1 & 1 & " \\
\hline 204 & 1,830 & $5.0 \pm 0.1$ & 2 & 2 & 1 & $n$ \\
\hline 205 & 1,770 & $6.3 \pm 0.1$ & 1 & 2 & 1 & - \\
\hline $206^{m+4}$ & 920 & $5.8 \pm 0.1$ & 1 & 3 & 1 & * \\
\hline
\end{tabular}

$2 \mathrm{~mA}$ a
\begin{tabular}{|c|c|c|c|c|c|c|}
\hline No. 301 & 1,300 & $6.7 \pm 0.05$ & 2 & 2 & 1 & 75 \\
302 & 1,880 & $4.8 \pm 0.05$ & 1 & 3 & 1 & - \\
303 & 720 & $4.3 \pm 0.2$ & 1 & 3 & 1 & - \\
304 & 1,900 & 5.0 & 1 & 2 & 1 & 7 \\
305 & 1,280 & $5.3 \pm 0.05$ & 1 & 6 & 2 & 4 \\
306 & 1.870 & $4.7 \pm 0.2$ & 2 & 3 & 1 & 4 \\
\hline
\end{tabular}

\begin{tabular}{|c|c|c|c|c|c|c|}
\hline No. 101 & 630 & $5.2 \pm 0.005$ & 0 & 0 & 0 & 15 L \\
102 & 690 & $5.0 \pm 0.1$ & 0 & 0 & 0 & $\vdots$ \\
103 & 1,080 & $5.7 \pm 0.1$ & 0 & 0 & 0 & $\vdots$ \\
104 & 1,980 & $4.9 \pm 0.1$ & 0 & 0 & 0 & $\vdots$ \\
105 & 2,000 & $4.8 \pm 0.1$ & 0 & 0 & 0 & $\vdots$ \\
106 & 1,900 & $5.2 \pm 0.1$ & 0 & 0 & 0 & $\vdots$ \\
\hline
\end{tabular}

$* 4$ 時間後死亡 $* * 30$ 時問後死亡 $* * * 1$ 時間後死亡 ※通電後24時問の観察, 但し死亡例は死亡前まで

り湼祭したが，陽性所见を琶めなかった。

№202を代表例として呈示する．体重 $680 \mathrm{~g}$ ， 通電用電極間抵抗 $4.1 \mathrm{~K} \Omega, A B R$ 用需極間抵 抗各 $4.3 \mathrm{~K} \Omega$ である. 電気性眼球偏位は, 通電 特, 短時閒小さく患側に偏位した後，健侧问き 1 回である，通需中は健側向き 3 回，遮電時は 患側问き 2 回である. 通電終了後の惏䣷下の徽 察では, 雱気性眼球偏位は認めない, しかし, この例では，22時間後覚醒時の観繁を行った結 果，右側内耳破壊術後に類似した姿勢を示すと ともに森獀性眼振を碓認した。再度 A B R 計測 の為麻䣷した絬果, 眼球運動は消失, 陽性所見 は認めなかった。

\section{䋶}

3) $2 \mathrm{~mA}$ 群

$2 \mathrm{~mA}$ 群は, 全例, 通電刺激に際し電気性 腿球偏位を認めた。即ち，通笔時は 1 ないし 2 回, 通電中は 2 から 6 回, 及び遮電時は 1 ない し 2 回である. 通電終了後, 24時間にわたり観 察したが，陽性所見は認めない。

代表例としてNa305を呈示する。体重 1,280 $\mathrm{g}$ ，通電用電極間抵抗 $5.4 \mathrm{~K} \Omega, A B R$ 用電極間 抵抗各 $5.3 \mathrm{~K} \Omega$ である。電気性眼球偏位は，通需 洔短時間小さく患側に偏位した後, 健側向き 1 回である，通電中は健側向き 6 回，遮電時は患 側向き 2 回である，通電終了後24時間にわたり 锰察したが, 電気性眼球偏位は認めなかった。

4) 小括

$10 \mathrm{~mA}$ 群及び $2 \mathrm{~mA}$ 群全例飞電気性眼球偏 位, とくに通電時に健側向き及び遮電時に患側 向きを認めたことは, 通電刺激が unipolar test として適切であったと考える，䏫醉下の電気性 眼球運動は，石原 ${ }^{3}$ が，家鬼を用いクロロホル ムあるいはエーテル林酔下に観察している，本 実験はこれをネンブタール 森䣷を用い証明し た。

なお，通電時，短時間患側向きの眼球偏位が あったことは報告がない，関谷 ${ }^{5)}$, 北原 ${ }^{19)} ら$ が GBST に扔いて, 初発波 (Initial wave) を報告しているが，電気性眼球偏位に打いて 相同のあのが認められたことは興味深い。しか しながら，梖酷下であること，及び通電法並に 通電電流量の相違があり，今後の検討を考元 る.

2 A B Rの成績

1) 対照群

本群各動物（№101加ら Na106）について，各 時点のA B R 各波潜時並に恥覚反応閥值を計測 した。 その成績を表 2 に示す。

№.104 の成績を代表例として図 5 に示す．各 波潜時の経時的变化は，左右とむにほとんど認 めない。

対照群ではA B R 波形は，ネンタブール麻酔 
下24時開の経過川，省叮な变化がないと考え た.

\section{2) $10 \mathrm{~mA}$ 群}

本群各動物（N.201加ら№206）について, 各 時点のAB R各波潜侍並に聡覚反応閔值を計测
した。 その成績を棐 3 に亦す。

№202 の成績を代挔例として四 6 に示し，以 下詳述する。

右A B Rに関して，まず，I波潜恃は通電南 後より短縮し， 1 及び 2 時間後最小值 $0.9 \mathrm{msec}$

表 2 対照群A B R, 各計測点の各波潜時並びに聴覚反応閥値の成績

\begin{tabular}{|c|c|c|c|c|c|c|c|c|c|c|c|c|c|}
\hline \multirow{2}{*}{\multicolumn{2}{|c|}{ No. 101}} & \multicolumn{6}{|c|}{ 住 $\mathrm{A}] \mathrm{J} \mathrm{K}$} & \multicolumn{6}{|c|}{$f_{\vec{r}} \quad \Lambda \mathrm{BK}$} \\
\hline & & I 波潪似 & 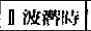 & 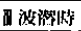 & 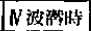 & 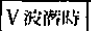 & 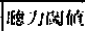 & 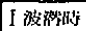 & 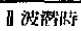 & 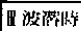 & 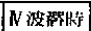 & $V$ 波翻牌 & 嘫力眓值 \\
\hline 欮 & ABR & 1.3 & 2.4 & 3.2 & 4.4 & 5.6 & -7 & 1.3 & 2.4 & 3.2 & 4.3 & 5.5 & -7 \\
\hline 愐後 & $"$ & 1.3 & 2.5 & 3.2 & 4.5 & 5.6 & -7 & 1.3 & 2.4 & 3.2 & 4.3 & 5.5 & -7 \\
\hline $\mathrm{I} \mathrm{hr}$ 後 & $"$ & 1.3 & 2.4 & 3.2 & 4.4 & 5.5 & -7 & 1.3 & 2.3 & 3.2 & 4.4 & 5.5 & -7 \\
\hline $2 \mathrm{hr}$ & $"$ & 1.3 & 2.3 & 3.2 & 4.4 & 5.5 & -7 & 1.3 & 2.3 & 3.2 & 4.4 & 5.4 & -7 \\
\hline $3 \mathrm{hr}$ & $n$ & 1.3 & 2.3 & 3.2 & 4.5 & 5.5 & -7 & 1.3 & 2.4 & 3.2 & 4.4 & 5.5 & -7 \\
\hline $12 \mathrm{hr}$ & $"$ & 1.3 & 2.3 & 3.3 & 4.5 & 5.5 & -7 & 1.3 & 2.3 & 3.2 & 4.4 & 5.5 & -7 \\
\hline $24 \mathrm{hr}$ & $n$ & 1.3 & 2.3 & 3.2 & 4.4 & 5.5 & -7 & 1.3 & 2.3 & 3.2 & 4.3 & 5.6 & -7 \\
\hline
\end{tabular}

No. 102

\begin{tabular}{|c|c|c|c|c|c|c|c|c|c|c|c|c|c|}
\hline 胎 & $\mathrm{ABR}$ & 1.2 & 2.4 & 3.2 & 4.4 & 5.4 & -7 & 1.2 & 2.3 & 3.2 & 4.5 & 5.5 & -7 \\
\hline 淔䥽 & $\pi$ & 1.2 & 2.4 & 3.2 & 4.4 & 5.5 & -7 & 1.2 & 2.4 & 3.3 & 4.5 & 5.5 & -7 \\
\hline $1 \mathrm{hr}$ 徏 & $"$ & 1.2 & 2.3 & 3.1 & 4.4 & 5.4 & -7 & 1.2 & 2.3 & 3.2 & 4.4 & 5.4 & -7 \\
\hline $2 \mathrm{hr}$ & $n$ & 1.2 & 2.3 & 3.2 & 4.4 & 5.4 & -7 & 1.2 & 2.3 & 3.2 & 4.4 & 5.5 & -7 \\
\hline $3 \mathrm{hr}$ & $"$ & 1.2 & 2.4 & 3.3 & 4.5 & 5.5 & -7 & 1.2 & 2.4 & 3.2 & 4.4 & 5.5 & -7 \\
\hline $12 \mathrm{hr}$ & $n$ & 1.2 & 2.3 & 3.2 & 4.4 & 5.5 & -7 & 1.2 & 2.3 & 3.2 & 4.4 & 5.5 & -7 \\
\hline $24 \mathrm{hr}$ & $"$ & 1.2 & 2.3 & 3.2 & 4.5 & 5.5 & -7 & 1.2 & 2.3 & 3.2 & 4.4 & 5.5 & -7 \\
\hline
\end{tabular}

No. 103

\begin{tabular}{|c|c|c|c|c|c|c|c|c|c|c|c|c|c|}
\hline 前 & ABR & 1.3 & 2.4 & 3.2 & 4.2 & 5.5 & -7 & 1.3 & 2.4 & 3,2 & 4.2 & 5.5 & -7 \\
\hline 亘传 & $"$ & 1.3 & 2.4 & 3.3 & 4.4 & 5.5 & -7 & 1.3 & 2.4 & 3.3 & 4.4 & 5.5 & -7 \\
\hline $1 \mathrm{hr}$ 役 & $"$ & 1.4 & 2.5 & 3.3 & 4.3 & 5.5 & -7 & 1.4 & 2.5 & 3.3 & 4.3 & 5.5 & -7 \\
\hline $2 h x$ & $n$ & 1.4 & 2.5 & 3.4 & 4.2 & 5.6 & -7 & 1.4 & 2.5 & 3.4 & 4.2 & 5.6 & -7 \\
\hline $3 \mathrm{hr}$ & $"$ & 1.4 & 2.4 & 3.2 & 4.2 & 5.5 & -7 & 1.4 & 2.4 & 3.2 & 4.2 & 5.5 & -7 \\
\hline $12 \mathrm{hr}$ & I & 1.4 & 2.5 & 3.3 & 4.3 & 5.6 & -7 & 1.4 & 2.5 & 3.3 & 4.3 & 5.5 & -7 \\
\hline $24 \mathrm{hr}$ & " & 1.4 & 2.5 & 3.2 & 4.4 & 5.6 & -7 & 1.4 & 2.5 & 3.2 & 4.4 & 5.6 & -7 \\
\hline
\end{tabular}

No. 104

\begin{tabular}{|c|c|c|c|c|c|c|c|c|c|c|c|c|c|}
\hline 前 & $A B R$ & 1.4 & 2.2 & 3.1 & 4.2 & 5.7 & -7 & $1: 4$ & 2.2 & 3.1 & 4.2 & 5.7 & -7 \\
\hline 活後 & $"$ & 1.4 & 2.1 & 3.1 & 4.2 & 5.7 & -7 & 1.4 & 2.1 & 3.1 & 4.2 & 5.7 & -7 \\
\hline $1 \mathrm{hr}$ 後 & $"$ & 1.4 & 2.2 & 3.2 & 4.2 & 5.7 & -7 & 1.3 & 2.2 & 3.2 & 4.2 & 5.6 & -7 \\
\hline $2 \mathrm{hr}$ & 11 & 1.3 & 2.3 & 3.1 & 4.2 & 5.5 & -7 & 1.3 & 2.3 & 3.1 & 4.2 & 5.5 & -7 \\
\hline $3 \mathrm{hr}$ & $"$ & 1.4 & 2.2 & 3.2 & 4.1 & 5.5 & -7 & 1.3 & 2.2 & 3.2 & 4.1 & 5.5 & -7 \\
\hline $12 \mathrm{hr}$ & 1 & 1.3 & 2.2 & 3.3 & 4.2 & 5.5 & -7 & 1.3 & 2.2 & 3.2 & 4.1 & 5.5 & -7 \\
\hline $24 \mathrm{hr}$ & $"$ & 1.4 & 2.3 & 3.3 & 4.3 & 5.6 & -7 & 1.4 & 2.3 & 3.3 & 4.3 & 5.6 & -7 \\
\hline
\end{tabular}

No. 105

\begin{tabular}{|c|c|c|c|c|c|c|c|c|c|c|c|c|c|}
\hline 首 & ABR & 1.3 & 2.3 & 3.2 & 4.3 & 5.5 & -7 & 1.3 & 2.2 & 3.2 & 4.3 & 5.5 & -7 \\
\hline 㚗 後 & $n$ & 1.3 & 2.3 & 3.4 & 4.4 & 5.6 & -7 & 1.3 & 2.3 & 3.3 & 4.4 & $?$ & -7 \\
\hline $1 \mathrm{hr}$ 㣪 & $n$ & 1.2 & 2.2 & 3.2 & 4.3 & $?$ & -7 & 1.2 & 2.2 & 3.3 & 4.3 & $?$ & -7 \\
\hline $2 \mathrm{hr}$ & N & 1.3 & 2.3 & 3.3 & 4.3 & 5.5 & -7 & 1.3 & 2.3 & 3.4 & 4.3 & 5.5 & -7 \\
\hline $3 \mathrm{hr}$ & $"$ & 1.3 & 2.3 & 3.3 & 4.3 & $?$ & -7 & 1.4 & 2.4 & 3.3 & 4.3 & 5.6 & -7 \\
\hline $12 \mathrm{hr}$ & $n$ & 1.5 & 2.4 & 3.3 & 4.4 & 5.6 & -7 & 1.5 & 2,4 & 3.2 & 4.3 & 5.5 & -7 \\
\hline $24 \mathrm{hr}$ & $"$ & 1.4 & 2.3 & 3.2 & 4.3 & 5.5 & -7 & 1.4 & 2.3 & 3.3 & 4.3 & 5.5 & -7 \\
\hline
\end{tabular}

No. 106

\begin{tabular}{|c|c|c|c|c|c|c|c|c|c|c|c|c|c|}
\hline 前 & $\mathrm{ABR}$ & 1.2 & 2.2 & 3.3 & 4.2 & 5.5 & 3 & 1.2 & 2.2 & 3.3 & 4.2 & 5.5 & 3 \\
\hline 㨁设 & $"$ & 1.2 & 2.2 & 3.4 & 4.2 & 5.6 & 3 & 1.3 & 2.2 & 3.4 & 4.2 & 5.6 & 3 \\
\hline 1 hr 伴 & 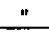 & 1.3 & 2.4 & 3.4 & 4.4 & 5.6 & 3 & 1.3 & 2.3 & 3.3 & 4.3 & 5.6 & 3 \\
\hline $2 \mathrm{hr}$ & $"$ & 1.3 & 2.4 & 3.4 & 4.4 & 5.6 & 3 & 1.3 & 2.4 & 3.4 & 4.3 & 5.6 & 3 \\
\hline $3 \mathrm{hr}$ & $"$ & 1.3 & 2.4 & 3.2 & 4.5 & 5.5 & 3 & 1.4 & 2.4 & 3.2 & 4.5 & 5.7 & 3 \\
\hline $12 \mathrm{hr}$ & $"$ & 1.4 & 2.2 & 3.3 & 4.2 & 5.5 & 3 & 1.4 & 2.3 & 3.3 & 4.2 & 5.6 & 3 \\
\hline $24 \mathrm{hr}$ & $n$ & 1.4 & 2.4 & 3.3 & 4.2 & 5.6 & 3 & 1.4 & 2.4 & 3.3 & 4.2 & 5.6 & 3 \\
\hline
\end{tabular}


を記録した，以後は，回復傾向を示した，一艼 波高は次第に低下し12時閒後率低を示したが, 24時間後には通電前に回復した，П波について

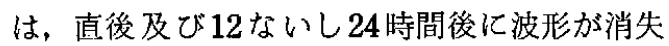
した。波北が記録できた 1 から 3 時間後は, 潜
洔の短維立泣波宮の低下を示した，III波及びN 波については，潜侍の短維を渄めた。そして24 侍間後には，I波而波及び IV波の位置に潜時 $3.5 \mathrm{msec}$ の一つのなだらかな波形を認めた。

$\mathrm{V}$ 波については，直後及び 1 洔間後に潜時の軽

表 $310 \mathrm{~m}$ A群A B R, 各計測点の各潜時並びに聴覚反応閔值の成續

\begin{tabular}{|c|c|c|c|c|c|c|c|c|c|c|c|c|c|}
\hline \multirow{2}{*}{\multicolumn{2}{|c|}{ No. $\quad 201$}} & \multicolumn{6}{|c|}{ 不 $\mathrm{ABR}$} & \multicolumn{6}{|c|}{ I: $\triangle B R$} \\
\hline & & I 波替洔 & 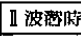 & 1 波筧时 & $N$ 波脖封 & V波潜时 & 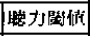 & 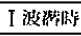 & 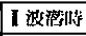 & 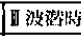 & 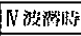 & V 波潜睆 & 㴔力䀝保 \\
\hline 前 & $\mathrm{ABR}$ & 1.2 & 2.2 & 3.2 & 4.3 & 5.5 & -7 & 1.2 & 2.2 & 3.2 & 4,3 & 5.5 & -7 \\
\hline 㨁後 & 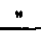 & 1.4 & 2.3 & 3.3 & 4.3 & 5.6 & 3 & 1.3 & 2.3 & 3.4 & 4.4 & 5.5 & -7 \\
\hline $1 \mathrm{hr}$ 㛶 & $"$ & 1.2 & 2.4 & 3.3 & 4.3 & 5.6 & 3 & 1.3 & 2.3 & 3.2 & 4.3 & 5.5 & -7 \\
\hline $2 \mathrm{hr}$ & $"$ & 1.2 & 2.2 & 3.2 & 4.1 & 5.3 & 13 & 1.2 & 2.3 & 3.0 & 4.1 & 5.3 & 3 \\
\hline $3 \mathrm{hr}$ & $"$ & 1.2 & 2.0 & $?$ & 3.8 & 5.3 & 13 & 1.3 & 2.2 & $?$ & 3.8 & $?$ & 13 \\
\hline $12 \mathrm{hr}$ & 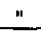 & & & & & & & & & & & & \\
\hline $24 \mathrm{hr}$ & $n$ & & & & & & & & & & & & \\
\hline
\end{tabular}

No. 202

\begin{tabular}{|c|c|c|c|c|c|c|c|c|c|c|c|c|c|}
\hline 前 & $\mathrm{ABR}$ & 1.3 & 2.4 & 3.2 & 4.4 & 5.5 & -7 & 1.3 & 2.5 & 3.1 & 4.3 & 5.5 & -7 \\
\hline 值极 & $n$ & 1.1 & $?$ & 2.8 & 4.3 & 5.6 & 3 & 1.2 & 2.4 & 3.4 & 4.2 & 5.6 & -7 \\
\hline $1 \mathrm{hr}$ 後 & 1 & 0.9 & 2.0 & 2.8 & 3.6 & 5.6 & -7 & 0.9 & 1.9 & 3.4 & 4.2 & 5.3 & -7 \\
\hline $2 h r$ & 1 & 0.9 & 2.0 & 2.9 & 3.5 & 5.2 & -7 & 1.0 & 2.4 & $?$ & 4.0 & 5.7 & -7 \\
\hline $3 \mathrm{hr}$ & $"$ & 1.0 & 1.9 & 2.8 & 3.8 & 5.0 & -7 & 1.2 & 2.3 & 3.2 & 4.5 & 5.5 & -7 \\
\hline $12 \mathrm{hr}$ & $"$ & 1.2 & $?$ & 3.1 & 4.3 & 5.3 & 3 & 1.3 & $?$ & 3.1 & 4.5 & $?$ & 3 \\
\hline $24 \mathrm{hr}$ & 1 & 1.0 & $?$ & 3.5 & $?$ & $?$ & 3 & 0.9 & 2.3 & $?$ & 3.8 & $?$ & 3 \\
\hline
\end{tabular}

No. 203

\begin{tabular}{|c|c|c|c|c|c|c|c|c|c|c|c|c|c|}
\hline 前 & $\mathrm{ABR}$ & 1.2 & 2.5 & 3.2 & 4.3 & 5.4 & -7 & 1.2 & 2.5 & 3.1 & 4.3 & 5.4 & -7 \\
\hline 值㖟 & $"$ & 1.0 & 2.2 & 3.0 & 4.0 & 5.6 & 3 & 1.1 & 1.9 & 2.8 & 4.3 & 5.3 & -7 \\
\hline $1 \mathrm{hr}$ 楼 & $"$ & 1.0 & 2.3 & 3.0 & 4.1 & 5.6 & 3 & 1.1 & 1.9 & 2.7 & 4.1 & 5.3 & -7 \\
\hline $2 \mathrm{hr}$ & 1 & 1.2 & 2.5 & 3.0 & 4.2 & 5.5 & 3 & 1.2 & 2.5 & 3.0 & 4.2 & 5.5 & 3 \\
\hline $3 \mathrm{hr}$ & $n$ & 1.0 & 2.5 & 3.0 & 3.9 & 5.2 & 3 & 1.2 & $?$ & 3.0 & 4.2 & 5.4 & 3 \\
\hline $12 \mathrm{hr}$ & $"$ & 1.3 & 2.5 & 3.2 & 4.2 & 5.4 & 3 & 1.3 & 2.6 & 3.4 & 4.3 & 5.4 & 3 \\
\hline $24 \mathrm{hr}$ & $"$ & 1.2 & 2.5 & 3.1 & 4.3 & 5.5 & 3 & 1.3 & 2.4 & 3.2 & 4.2 & 5.7 & 3 \\
\hline
\end{tabular}

No. 204

\begin{tabular}{|c|c|c|c|c|c|c|c|c|c|c|c|c|c|}
\hline 首列 & ABR & 1.2 & 2.1 & 3.1 & 4.3 & 5.5 & -7 & 1.2 & 2.1 & 3.2 & 4.3 & 5.5 & -7 \\
\hline 直後 & " & 1.2 & 2.1 & 3.0 & 4.3 & 5.3 & -7 & 1.1 & 2.1 & 3.1 & 4.3 & 5.4 & -7 \\
\hline $1 \mathrm{hr}$ 後 & $n$ & 1.1 & 2.0 & 3.2 & 4.4 & 5.2 & 3 & 1.2 & 2.1 & 3.3 & 4.4 & 5.4 & -7 \\
\hline $2 \mathrm{hr}$ & - & 1.0 & 2.0 & 3.2 & 4.3 & 5.2 & 3 & 2.1 & 2.1 & 3.2 & 4.4 & 5.4 & -7 \\
\hline $3 \mathrm{hr}$ & n & 1.0 & 2.0 & 3.1 & 4.3 & 5.0 & -7 & 1.0 & 2.1 & 3.2 & 4.4 & 5.4 & 3 \\
\hline $12 \mathrm{hr}$ & " & 1.0 & 2.2 & 3.1 & 4.4 & 5.3 & -7 & 1.3 & 2.2 & 3.1 & 4.5 & 5.3 & 3 \\
\hline $24 \mathrm{hr}$ & $"$ & 1.0 & 1.8 & 3.1 & 4.4 & 5.8 & 3 & 1.0 & 2.0 & 3.0 & 4.2 & 5.4 & 3 \\
\hline
\end{tabular}

No. 205

\begin{tabular}{|c|c|c|c|c|c|c|c|c|c|c|c|c|c|}
\hline 前 & $\mathrm{ABR}$ & 1.3 & 2.4 & 3.3 & 4.4 & 5.4 & -7 & 1.3 & 2.3 & 3.3 & 4.4 & 5.4 & -7 \\
\hline 啇後 & $"$ & 1.2 & 2.5 & 3.3 & 4.6 & 5.3 & 3 & 1.1 & 2.3 & 3.3 & 4.5 & 5.5 & 3 \\
\hline $1 \mathrm{hr}$ 後 & $"$ & 1.4 & 2.3 & 3.5 & 4.5 & 5.6 & 3 & 1.3 & 2.5 & 3.5 & 4.6 & 5.5 & 3 \\
\hline $2 \mathrm{hr}$ & $n$ & 1.4 & 2.3 & 3.4 & 4.8 & 5.6 & 3 & 1.2 & 2.4 & 3.4 & 4.5 & 5.5 & 3 \\
\hline $3 \mathrm{hr}$ & $n$ & 1.2 & 2.4 & 3.4 & 4.3 & 5.8 & 3 & 1.2 & 2.2 & 3.2 & 4.1 & 5.5 & 3 \\
\hline $12 \mathrm{hr}$ & $"$ & 1.1 & 2.4 & 3.4 & 4.1 & 5.4 & 3 & 1.3 & $?$ & 2.8 & 3.9 & 5,4 & 3 \\
\hline $24 \mathrm{hr}$ & " & 1.1 & $?$ & 2.8 & 4.3 & 5.5 & 3 & 1.3 & $?$ & 2.7 & 4.0 & 5.4 & 3 \\
\hline
\end{tabular}

No. 206

\begin{tabular}{|l|l|l|l|l|l|l|l|l|l|l|l|l|}
\hline 前 $\mathrm{ABR}$ & 1.3 & 2.4 & 3.4 & 4.3 & 5.4 & 3 & 1.3 & 2.3 & 3.4 & 4.4 & 5.5 & 3 \\
\hline 淔 後 & 1.5 & 2.5 & 3.6 & 4.5 & 5.3 & 13 & 1.3 & 2.5 & 3.5 & 4.3 & 5.5 & 3 \\
\hline $1 \mathrm{hr}$ " & 1.6 & 2.6 & 3.7 & 4.5 & 5.3 & 23 & 1.4 & 2.6 & 3.6 & 4.3 & 5.5 & 13 \\
\hline $2 \mathrm{hr}$ " & & & & & & & & & & & & \\
\hline $3 \mathrm{hr}$ " & & & & & & & & & & & & \\
\hline $12 \mathrm{hr}$ & & & & & & & & & & & & \\
\hline $24 \mathrm{hr}$ & & & & & & & & & & & & \\
\hline
\end{tabular}




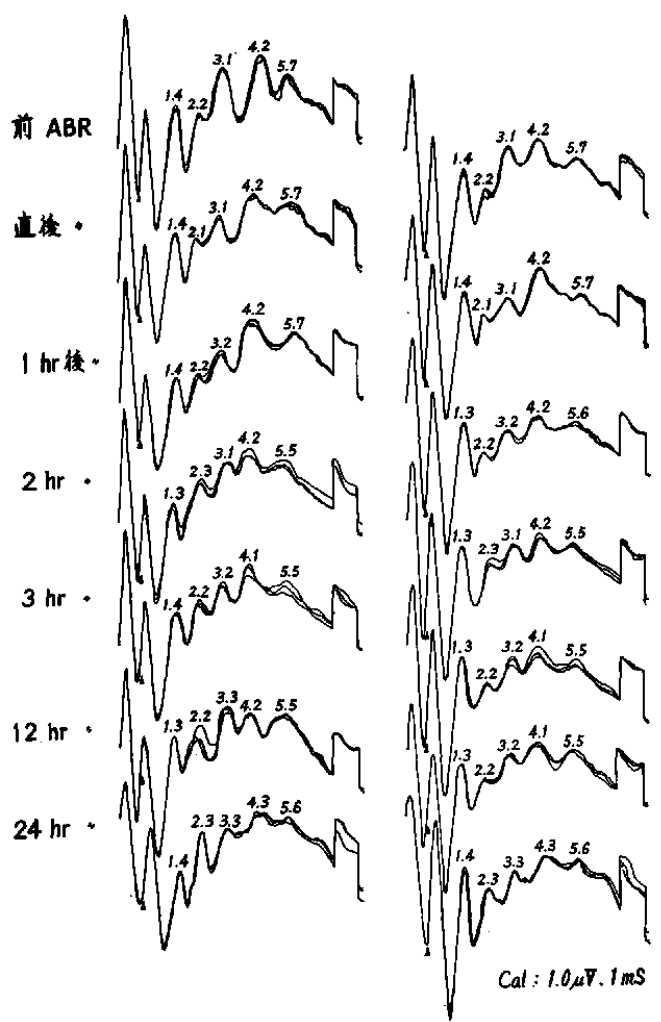

图 5 対照群代表例（No.104）AB R
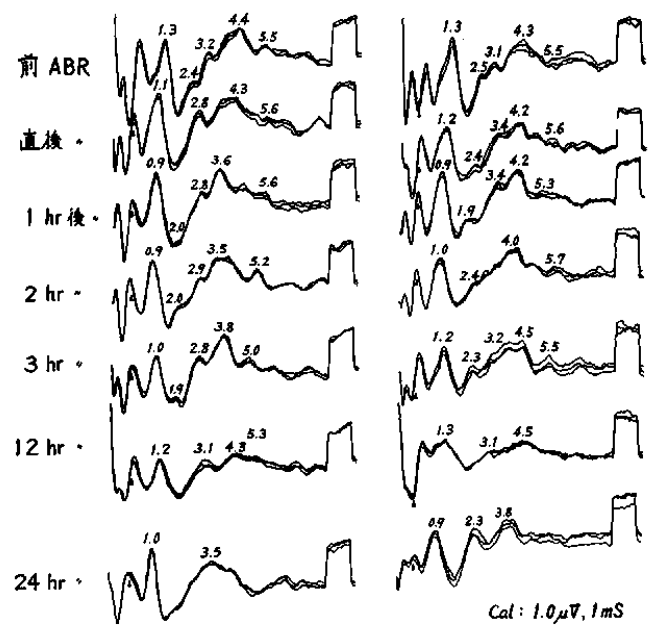

図 $610 \mathrm{~mA}$ 通電群代表例（Na202）A B R

度延長，そして 2 から12時間後に潜時の短縮を 示した後，24時間後に波形が消失した。
左ABRに関して，まずI波は，潜時並に波 阔が右 I 波とほぼ平行して変化した。但し，12 侍間後の波㣋は, 右 I 波と比較しても変化して いた。【波については，通電直後加ら 3 時間後 に潜時の短縮並に波高の低下，また12時間後に 波形の消失を示した後，24時間後に変形した潜 時 $2.3 \mathrm{msec}$ の波形を認めた。波について は，直後及び 1 時間後に潜時の延長， 2 時間後 に波形の消失を認めたが， 3 時間後は潜時，波 形が回復した。 しかし，さらに12及び24時間後 は波非が変化した．V波については，直後から 2 洔間後に潜時の短縱， 3 及び 12 時間後に延長 を認めた．24時間後，IV波は，潜時 $3.8 \mathrm{msec}$ のIII波に含まれるかあるいは消失と考えた．V 波については，3 時間後まで潜時の変動を示し た後，12時間後波形が消失した。

聴覚反応閔值は通電前， -7dBSPL であった が，12ないし24時間後は，左右ともに 3dBSPL と軽度上昇した。

3) $2 \mathrm{~mA}$ 群

本群各動物（Na301加ら Na306）について，各 洔点のA B R 各波潜洔並に聴覚反心閶值を計測 した，その成績を表 4 亿示す。

NN305の成績を代表例として図 7 亿示し，以 下詳述する。

右A B Rにおいて，I波潜時は， 1 時間後と 3 時間後以降において軽度延長した。 II 波潜時 は軽度延長傾向を認めた。波潜時は 2 ないし 3 時間後, 潜時の延長及び波形の変化を示し た. 12ないし24時間後はほぼ正常であった。 $\mathrm{N}$ 波潜時は直後より延長傾向を認めたが，12ない し24時間後は通電前と変わらない.V波潜時 は，3 時間後軽度延長を認めたが 24 時間後は通 電前之変わらない。

左A B Rにおいて，I 波潜時は， 1 時間後に 柽度短縮し， 3 時間後以降軽度延長した。 II波 潜時むほぼ同様の変化であった。波潜持は延 長傾向を認め, 3 時間後に最大の変化を示し， 24時間後む $3.6 \mathrm{msec}$ と延長していた。 IV 波潜 封は， 2 ないし 3 時間後軽度延長したが，12な 


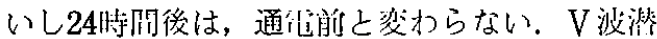
寺は右侧とほぼ同じ変化であった。

嵮覚反応閶值は通管前, 左右ともに $-7 \mathrm{~dB}$ SPL であり，通電後も変わらない.
4) 小括

まず裴 2 をもとに，刘照群各動物のAB R各 潜恃について $\mathrm{t}$ 検定を行い，経侍变化の有無を 検傠した。その結果左右各波潜時全てに有意娄 は慜めない（ $\mathrm{P}<0.05 ）$ 。次に対照群と $10 \mathrm{~mA}$

表 $42 \mathrm{~mA}$ 群A B R, 各計測点の各波潜時並びに聴覚反応閵値の成績

\begin{tabular}{|c|c|c|c|c|c|c|c|c|c|c|c|c|c|}
\hline \multirow{2}{*}{\multicolumn{2}{|c|}{ No. 301}} & \multicolumn{6}{|c|}{$\begin{array}{ll}1 ; & A B R\end{array}$} & \multicolumn{6}{|c|}{$1_{1}: \quad A B K$} \\
\hline & & 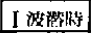 & 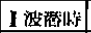 & 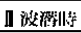 & N波洌睡 & 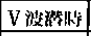 & 能力组话 & 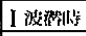 & 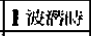 & 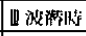 & N 波帮时 & V波替时 & 㺊力国国 \\
\hline 前 & $\mathrm{ABR}$ & 1.3 & 2.3 & 3.3 & 4.4 & 5.5 & 3 & 1.3 & 2.3 & 3.3 & 4.4 & 5.5 & 3 \\
\hline 活後後 & $"$ & 1.3 & 2.4 & 3.4 & 4.6 & 5.6 & 3 & 1.3 & 2.4 & 3.4 & 4.4 & 5.6 & 3 \\
\hline $1 \mathrm{hr}$ 後 & $"$ & 1.5 & 2.5 & 3.5 & 4.6 & 5.7 & 3 & 1.3 & 2.4 & 3.5 & 4.6 & 5.6 & 3 \\
\hline $2 \mathrm{hr}$ & $n$ & 1.3 & 2.4 & 3.3 & 4.5 & 5.5 & 3 & 1.3 & 2.3 & 3.3 & 4.5 & 5.5 & 3 \\
\hline $3 \mathrm{hr}$ & $"$ & 1.3 & 2.4 & 3.4 & 4.5 & 5.6 & 3 & 1.3 & 2.5 & 3.3 & 4.5 & 5.6 & 3 \\
\hline $12 \mathrm{hr}$ & $"$ & 1.2 & 2.5 & 3.3 & 4.3 & 5.4 & 3 & 1.3 & 2.5 & 3.3 & 4.4 & 5.6 & 3 \\
\hline $24 \mathrm{hr}$ & $"$ & 1.3 & 2.4 & 3.3 & 4.4 & 5.5 & 3 & 1.4 & 2.3 & 3.3 & 4.4 & $?$ & 3 \\
\hline
\end{tabular}

\begin{tabular}{|c|c|c|c|c|c|c|c|c|c|c|c|c|c|}
\hline ihis & ABR & 1.3 & 2.3 & 3.3 & 4.3 & 5.5 & -7 & 1.3 & 2.3 & 3.3 & 4.4 & 5.6 & -7 \\
\hline 淮㣞 & $n$ & 1.5 & 2.4 & 3.4 & 4.3 & 5.5 & -7 & 1.4 & 2.4 & 3.4 & 4.3 & 5.5 & -7 \\
\hline $1 \mathrm{hr}$ 後 & $"$ & 1.4 & 2.5 & 3.5 & 4.5 & 5.6 & -7 & 1.4 & 2.5 & 3.5 & 4.5 & 5.5 & -7 \\
\hline $2 \mathrm{hr}$ & $"$ & 1.3 & 2.3 & 3.4 & 4.4 & 5.6 & -7 & 1.3 & 2.3 & 3.3 & 4.3 & 5.5 & -7 \\
\hline $3 \mathrm{hr}$ & $"$ & 1.3 & 2.3 & 3.2 & 4.4 & 5.6 & -7 & 1.3 & 2.3 & 3.2 & 4.4 & 5.5 & -7 \\
\hline $12 \mathrm{hr}$ & " & 1.4 & 2.2 & 3.3 & 4.5 & 5.7 & -7 & 1.4 & 2.2 & 3.2 & 4.3 & 5.5 & -7 \\
\hline $24 \mathrm{hr}$ & $"$ & 1.4 & 2.3 & 3.4 & 4.3 & 5.5 & -7 & 1.4 & 2.3 & 3.3 & 4.4 & 5.5 & -7 \\
\hline
\end{tabular}

\begin{tabular}{|c|c|c|c|c|c|c|c|c|c|c|c|c|c|}
\hline 肖行 & ABR & 1.5 & 2.4 & 3.4 & 4.3 & 5.7 & -7 & 1.5 & 2.5 & 3.4 & 4.3 & 5.7 & -7 \\
\hline 苻後 & $"$ & 1.4 & 2.4 & 3.3 & 4.4 & 5.7 & -7 & 1.5 & 2.4 & 3.3 & 4.4 & 5.7 & -7 \\
\hline $1 \mathrm{hr}$ 业 & $"$ & 1.6 & 2.4 & 3.2 & 4.5 & 5.6 & -7 & 1.5 & 2.4 & 3.2 & 4.4 & 5.6 & -7 \\
\hline $2 \mathrm{hr}$ & $"$ & 1.6 & 2.4 & 3.2 & 4.5 & 5.5 & -7 & 1.7 & 2.5 & 3.4 & 4.3 & 5.5 & -7 \\
\hline $3 \mathrm{hr}$ & $"$ & 1.5 & 2.4 & 3.1 & 4.6 & 5.4 & -7 & 1.7 & 2.6 & 3.2 & 4.2 & 5.3 & -7 \\
\hline $12 \mathrm{hr}$ & $\pi$ & 1.5 & 2.3 & 3.5 & 4.3 & 5.5 & 3 & 1.7 & 2.6 & 3.5 & 4.4 & 5.5 & 3 \\
\hline $24 \mathrm{hr}$ & $"$ & 1.6 & 2.6 & 3.6 & 4.4 & 5.7 & -7 & 1.5 & 2.4 & 3.5 & 4.3 & 5.7 & -7 \\
\hline
\end{tabular}

\begin{tabular}{|c|c|c|c|c|c|c|c|c|c|c|c|c|c|c|}
\hline 前 & & ABR & 1.4 & 2.4 & 3.4 & 4.4 & 5.5 & -7 & 1.4 & 2.4 & 3.4 & 4.4 & 5.4 & -7 \\
\hline 直 & & $"$ & 1.3 & 2.4 & 3.4 & 4.4 & 5.5 & -7 & 1.3 & 2.4 & 3.4 & 4.4 & 5.5 & -7 \\
\hline & $\mathrm{hr}$ 楼 & $"$ & 1.2 & 2.3 & 3.3 & 4.4 & 5.6 & -7 & 1.1 & 2.4 & 3.3 & 4.5 & 5.6 & -7 \\
\hline 2 & $\mathrm{hr}$ & $n$ & 1.2 & 2.3 & 3.3 & 4.3 & 5.5 & -7 & 1.2 & 2.4 & 3.3 & 4.3 & 5.5 & -7 \\
\hline 3 & $\mathrm{hr}$ & $n$ & 1.3 & 2.3 & 3.6 & 4.3 & 5.3 & -7 & 1.3 & 2.3 & 3.5 & 4.3 & 5.4 & -7 \\
\hline 12 & & $n$ & 1.5 & 2.4 & 3.3 & 4.2 & 5.5 & -7 & 1.5 & 2.4 & 3.3 & 4.2 & 5.5 & -7 \\
\hline 24 & $\mathrm{hr}$ & 1 & 1.3 & 2.4 & 3.3 & 4.2 & 5.3 & -7 & 1.3 & 2.4 & 3.3 & 4.2 & 5.3 & -7 \\
\hline
\end{tabular}

\begin{tabular}{|c|c|c|c|c|c|c|c|c|c|c|c|c|c|}
\hline 前 & $\mathrm{ABR}$ & 1.2 & 2.3 & 3.4 & 4.5 & 5.7 & -7 & 1.2 & 2.3 & 3.3 & 4.5 & 5.6 & -7 \\
\hline 通後 & $"$ & 1.2 & 2.3 & 3.4 & 4.8 & 5.8 & -7 & 1.2 & 2.3 & 3.4 & 4.5 & 5.8 & -7 \\
\hline $1 \mathrm{hr}$ 镥 & 1 & 1.3 & 2.4 & 3.4 & 4.9 & 5.8 & -7 & 1.2 & 2.3 & 3.4 & 4.4 & 5.7 & -7 \\
\hline $2 \mathrm{hr}$ & $"$ & 1.2 & 2.3 & 3.8 & 4.7 & 5.8 & -7 & 1.2 & 2.2 & 3.7 & 4.6 & 5.8 & -7 \\
\hline $3 \mathrm{hr}$ & $"$ & 1.3 & 2.4 & 3.7 & 4.6 & 6.0 & -7 & 1.3 & 2.4 & 3.8 & 4.7 & 6.1 & -7 \\
\hline $12 \mathrm{hr}$ & $\pi$ & 1.3 & 2.4 & 3.4 & 4.5 & 5.8 & -7 & 1.3 & 2.4 & 3.6 & 4.5 & 5.8 & -7 \\
\hline $24 \mathrm{hr}$ & $\pi$ & 1.3 & 2.5 & 3.5 & 4.5 & 5.7 & -7 & 1.3 & 2.5 & 3.6 & 4.5 & 5.7 & -7 \\
\hline
\end{tabular}

No. 306

\begin{tabular}{|ll|l|l|l|l|l|l|l|l|l|l|l|l|}
\hline 前 & $\mathrm{ABR}$ & 1.3 & 2.3 & 3.4 & 4.4 & 5.6 & -7 & 1.3 & 2.3 & 3.4 & 4.4 & 5.6 & -7 \\
\hline $\mathrm{Wi}$ 後 & $"$ & 1.2 & 2.2 & 3.3 & 4.4 & 5.5 & -7 & 1.3 & 2.2 & 3.4 & 4.3 & 5.5 & -7 \\
\hline $1 \mathrm{hr}$ & " & 1.4 & 2.4 & 3.4 & 4.2 & 5.4 & -7 & 1.4 & 2.3 & 3.5 & 4.2 & 5.4 & -7 \\
\hline $2 \mathrm{hr}$ & $"$ & 1.4 & 2.4 & 3.3 & 4.5 & $?$ & -7 & 1.4 & 2.4 & 3.3 & 4.5 & $?$ & -7 \\
\hline $3 \mathrm{hr}$ & $"$ & 1.4 & 2.4 & 3.5 & 4.4 & 5.5 & -7 & 1.4 & 2.4 & 3.4 & 4.4 & 5.5 & -7 \\
\hline $12 \mathrm{hr}$ & $"$ & 1.4 & 2.3 & 3.4 & 4.3 & 5.5 & -7 & 1.4 & 2.3 & 3.4 & 4.3 & 5.5 & -7 \\
\hline $24 \mathrm{hr}$ & " & 1.4 & 2.4 & 3.4 & 4.4 & 5.6 & -7 & 1.4 & 2.3 & 3.4 & 4.4 & 5.6 & -7 \\
\hline
\end{tabular}




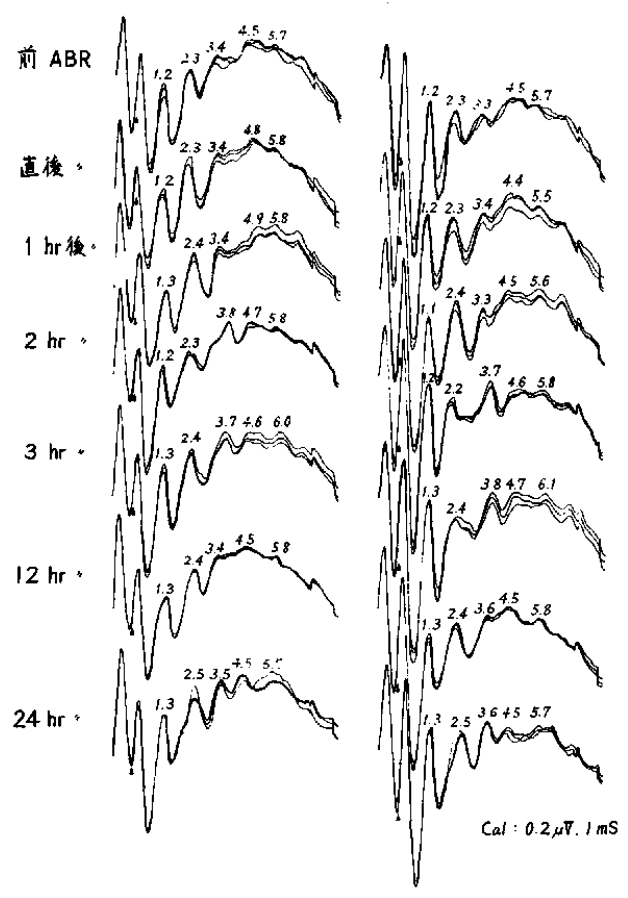

図 $72 \mathrm{~mA}$ 通電群代表例（№.305） A B R

群間及び対照群と $2 \mathrm{~mA}$ 群間の通笔前 A B R 各 波潜恃の検討を行った。 その結果, 対紧群と10 $\mathrm{mA}$ 群間の通電前・各波潜恃間には，有意养は 認めない $(\mathrm{P}<0.05)$. しかし, 対照群と $2 \mathrm{~mA}$ 群間の通電前A B Rのうち，左右四波潜時は有 意な差を認めた。 $(P<0.05)$. 従って以下の 2 $\mathrm{mA}$ 群左右而波潜恃についての検討は原データ をもとに $\mathrm{t}$ 㭘定を行うととむに，各動物の通電 前各波潜時を原点とした差の検討を併わせて行 うこととした。

対照群, $10 \mathrm{~mA}$ 群，及び $2 \mathrm{~mA}$ 群の各波潜牌 平均值並に祭準偏差を求めた（表 5 )。最初に $10 \mathrm{~mA}$ 群と対照群との群間比較を行った。 結果, 右 I 波潜時及びV波潜封は有意差を涊める（P <0.01). また右 III 波潜時並に左 I 波及びV波

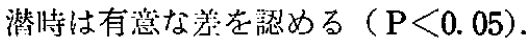

次に $2 \mathrm{~mA}$ 群と対照群との群間比較を行。 た。結果，右 I 波，四波，IV波及びV波潜時並

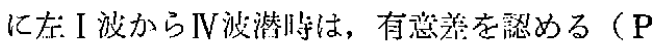

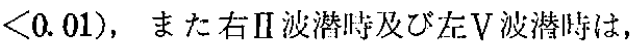

有意な差を認める $(\mathrm{P}<0.05)$.

次に同様に $10 \mathrm{~mA}$ 群と $2 \mathrm{~mA}$ 群との群間比較 を行った．結果, 右 I 波, III波及びV波潜時と 左 I 波，III没，IV波及びV波潜時は，有意差を 認める（ $\mathrm{P}<0.01 ）$ ．また右V波潜時及び左П 波潜時は有意な差を認める（ $\mathrm{P}<0.05 ）$.

波形について, 波形消失は, $10 \mathrm{~mA}$ 群におい

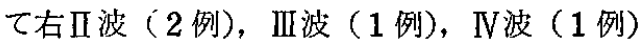

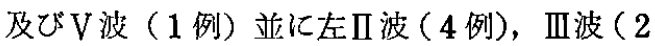
例)，及びV波 ( 2 例) に認める。 $2 \mathrm{~mA}$ 群は 右V波（1 例) 及び左V波（1例）に認める。 一方対照群においては波形消失は認めない，波 玥消失は明らかな変化と考えられるので, 波形 消失と潜時の変化から対照群と $10 \mathrm{~mA}$ 群との群 間には, 左非通電側 $\mathrm{N}$ 波潜時を除く各波に, 有 急差を認める. 同様に $2 \mathrm{~mA}$ 群と対照群では, 通電側並に非通電側全波に有意差を認める.同 様に $10 \mathrm{~mA}$ 群と $2 \mathrm{~mA}$ 群では，全波に有意差を 認める。

次に, 各計測点に抢ける, $10 \mathrm{~mA}$ 群と対照群 及び $2 \mathrm{~mA}$ 群と対照群との群間比較を行った. $10 \mathrm{~mA}$ 群之対照群との群間比較の結果（図 8 ), 3 及び 24 時間後の右 I 波潜時, 12時間後の右V 波潜時及び 1 時間後の左非通電側 V 波潜時は, 有意差を認める（ $\mathrm{P}<0.01 ）$ ，また右㑡におい ては， 12 時間後のI波及び 3 時間後のIV波潜 洔, 左側においては, 直後, 2 及び 3 時間後の

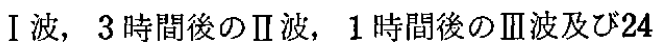
特間後のIV波潜時は，有意な差を認める（ $\mathrm{P}<$ 0.05). 同様に $2 \mathrm{~mA}$ 群と対照群との群間比較 を行った結果（図 9)，2 時間後の右 $N$ 波潜時 及び 1 時間後の左V波潜時に有意な差を認める $(\mathrm{P}<0.05)$.

通電前A B R の各波潜時を原点とし，通電後 の変化量を各動物毎に求めた成績を図10に示 す. 対照群に比較し, $10 \mathrm{~mA}$ 群及び $2 \mathrm{~mA}$ 群の 変化量の大きさが明瞭である. 10mA 群では, 右各波潜洔並に左非通電側 II - III - IV 波潜時の 変化量が大であること，また左V波を除き，直 後から 3 洔關後の閂の变化黛が大であるととが 
わかる。

$2 \mathrm{~mA}$ 群では, 左右III ・ IV ・V 波潜時の变化 量が大であること，また 2 時間後から 3 時間後 の間の変化量が大であることがわかる.

\section{3 病理組織学的検索の成績}

対照群, $10 \mathrm{~mA}$ 群及び $2 \mathrm{~mA}$ 群の病理組織 学的所見をまとめ表 6 亿示す. 表中 “十” は陽 性所罗, 即ちニューロンではとくに Nissl 小体

表 5 対照群, $10 \mathrm{~m}$ A群及び $2 \mathrm{~mA}$ A群A B Rの各計測点各波潜時の平均值並びに標準偏差

\begin{tabular}{|c|c|c|c|c|c|c|c|c|c|c|c|c|}
\hline & \multirow{2}{*}{ 㷊 } & \multirow{2}{*}{ 群 } & \multicolumn{2}{|c|}{ I 波潜 时 } & \multicolumn{2}{|c|}{ 』波游 $\|_{j}$} & \multicolumn{2}{|c|}{ 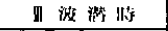 } & \multicolumn{2}{|c|}{ 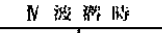 } & \multicolumn{2}{|c|}{$\mathrm{V}$ 波 淑 怗 } \\
\hline & & & 平均 & 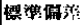 & 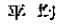 & 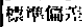 & sF. tol & 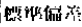 & 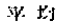 & 懒谓绡, & .7. 均 & 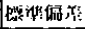 \\
\hline \multirow{7}{*}{ 仿 } & 遄 & $A B R$ & 2.28 & 0.075 & 2.32 & 0.098 & 3.20 & 0.063 & 4.28 & 0.098 & 5.53 & 0.103 \\
\hline & 南 & " & 1.28 & 0.075 & 2.32 & 0.147 & 3.27 & 0.121 & 4.35 & 0.122 & 5.58 & 0.075 \\
\hline & $1 \mathrm{hr}$ 後 & $"$ & 1.30 & 0.089 & 2.33 & 0.121 & 3.23 & 0.103 & 4.33 & 0.082 & 5.54 & 0.114 \\
\hline & $2 \mathrm{hr}$ & $"$ & 1.30 & 0.063 & 2.35 & 0.084 & 3.27 & 0.121 & 4.32 & 0.098 & 5.52 & 0.075 \\
\hline & $3 \mathrm{hr}$ & $"$ & 1.32 & 0.075 & 2.33 & 0.082 & 3.23 & 0.052 & 4.35 & 0.176 & 5.50 & 0.0 \\
\hline & $12 \mathrm{hr}$ & $"$ & 1.35 & 0.105 & 2.32 & 0.117 & 3.28 & 0.041 & 4.33 & 0.121 & 5.53 & 0.052 \\
\hline & $24 \mathrm{hr}$ & " & 1.35 & 0.084 & 2.35 & 0.084 & 3.23 & 0.052 & 4.35 & 0.105 & 5.55 & 0.055 \\
\hline
\end{tabular}

\begin{tabular}{|c|c|c|c|c|c|c|c|c|c|c|c|c|}
\hline \multirow{7}{*}{$f i:$} & 湖 & $\mathrm{ABR}$ & 1.28 & 0.075 & 2.28 & 0.098 & 3.20 & 0.063 & 4.28 & 0.117 & 5.53 & 0.082 \\
\hline & 陑嵝 & " & 1.30 & 0.063 & 2.30 & 0.126 & 3.27 & 0.103 & 4.33 & 0.121 & 5.56 & 0.089 \\
\hline & $1 \mathrm{hr}$ 熖 & $\pi$ & 1.28 & 0.075 & 2.30 & 0.110 & 3.25 & 0.055 & 4.32 & 0.075 & 3.52 & 0.084 \\
\hline & $2 \mathrm{hr}$ & $n$ & 1.30 & 0.063 & 2.35 & 0.084 & 3.28 & 0.133 & 4.30 & 0.089 & 5.52 & 0.084 \\
\hline & $3 \mathrm{hr}$ & $"$ & 1.33 & 0.082 & 2.37 & 0.082 & 3.22 & 0.040 & 4.32 & 0.147 & 5.55 & 0.084 \\
\hline & $12 \mathrm{hr}$ & $"$ & 1.35 & 0.105 & 2.33 & 0.103 & 3.23 & 0.052 & 4.28 & 0.117 & 5.51 & 0.041 \\
\hline & $24 \mathrm{hr}$ & $\pi$ & 1.35 & 0.084 & 2.35 & 0.084 & 3.25 & 0.055 & 4.32 & 0.075 & 5.57 & 0.052 \\
\hline
\end{tabular}

\begin{tabular}{|c|c|c|c|c|c|c|c|c|c|c|c|c|}
\hline \multirow{2}{*}{\multicolumn{2}{|c|}{$10 \mathrm{~mA}$}} & \multirow{2}{*}{ 洋 } & \multicolumn{2}{|c|}{ 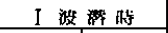 } & \multicolumn{2}{|c|}{ 【波裳时 } & \multicolumn{2}{|c|}{ 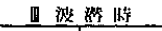 } & \multicolumn{2}{|c|}{$N$ 波路时 } & \multicolumn{2}{|c|}{ 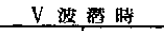 } \\
\hline & & & 壮均 & 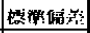 & 平地 & 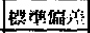 & W. $\mathrm{H}_{-1}$ & 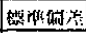 & 壮地 & 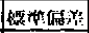 & 取喝 & 㯇湒偏差 \\
\hline \multirow{7}{*}{ ti } & 流 & $\mathrm{ABR}$ & 1.25 & 0.055 & 2.33 & 0.151 & 3.23 & 0.103 & 4.33 & 0.052 & 5.45 & 0.055 \\
\hline & 住挠 & $"$ & 1.23 & 0.186 & 2.32 & 0.179 & 3.17 & 0.288 & 4.33 & 0.207 & 5.45 & 0.164 \\
\hline & 1 hr 焲 & " & 1.20 & 0.261 & 2.27 & 0.234 & 3.25 & 0.327 & 4.23 & 0.344 & 5.48 & 0.183 \\
\hline & $2 \mathrm{hr}$ & $n$ & 1.14 & 0.195 & 2.20 & 0.212 & 3.14 & 0.195 & 4.18 & 0.466 & 5.36 & 0.182 \\
\hline & $3 \mathrm{hr}$ & $n$ & 1.08 & 0.110 & 2.16 & 0.270 & 3.08 & 0.250 & 4.02 & 0.259 & 5.26 & 0.329 \\
\hline & $12 \mathrm{hr}$ & $\pi$ & 1.15 & 0.129 & 2.43 & 0.058 & 3.20 & 0.141 & 4.25 & 0.129 & 5.35 & 0.058 \\
\hline & $24 \mathrm{hr}$ & " & 1.08 & 0.096 & 2.15 & 0.495 & 3.13 & 0.287 & 4.33 & 0.058 & 5.60 & 0.173 \\
\hline
\end{tabular}

\begin{tabular}{|c|c|c|c|c|c|c|c|c|c|c|c|c|}
\hline \multirow{7}{*}{ tr } & i) & ABR & 1.25 & 0.055 & 2.32 & 0.160 & 3.22 & 0.117 & 4.33 & 0.052 & 5.47 & 0.052 \\
\hline & 低後 & $"$ & 1.18 & 0.098 & 2.25 & 0.217 & 3.25 & 0.259 & 4.33 & 0.103 & 5.47 & 0.103 \\
\hline & $1 \mathrm{hr}$ 秝 & $"$ & 1.20 & 0.179 & 2.22 & 0.299 & 3.28 & 0.319 & 4.32 & 0.172 & 5.41 & 0.098 \\
\hline & $2 \mathrm{hr}$ & $"$ & 1.14 & 0.089 & 2.34 & 0.152 & 3.15 & 0.191 & 4.24 & 0.207 & 5.48 & 0.148 \\
\hline & $3 \mathrm{hr}$ & $"$ & 1.18 & 0.110 & 2.20 & 0.082 & 3.15 & 0.100 & 4.20 & 0.273 & 5.45 & 0.058 \\
\hline & $12 \mathrm{hr}$ & 1 & 1.30 & 0.0 & 2.40 & 0.283 & 3.10 & 0.245 & 4.30 & 0.283 & 5.36 & 0.058 \\
\hline & $24 \mathrm{hr}$ & $"$ & 1.13 & 0.206 & 2.23 & 0.208 & 2.97 & 0.252 & 4.05 & 0.191 & 5.50 & 0.173 \\
\hline
\end{tabular}

\begin{tabular}{|c|c|c|c|c|c|c|c|c|c|c|c|c|}
\hline & \multirow{2}{*}{$2 \mathrm{~mA}$} & \multirow{2}{*}{ 碓 } & \multicolumn{2}{|c|}{ 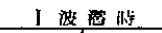 } & \multicolumn{2}{|c|}{ 【波整惦 } & \multicolumn{2}{|c|}{ 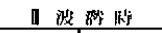 } & \multicolumn{2}{|c|}{$N$ 波市畹 } & \multicolumn{2}{|c|}{ V波潜 時 } \\
\hline & & & 平均 & 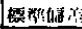 & . & 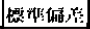 & . W 5 & 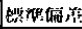 & 徆地 & 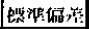 & W. 她 & 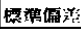 \\
\hline \multirow{7}{*}{ 右 } & 掉 & $\mathrm{ABR}$ & 1.33 & 0.103 & 2.33 & 0.052 & 3.37 & 0.052 & 4.38 & 0.075 & 5.58 & 0.098 \\
\hline & 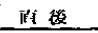 & $"$ & 1.32 & 0.117 & 2.35 & 0.084 & 3.37 & 0.052 & 4.48 & 0.183 & 5.60 & 0.126 \\
\hline & $1 \mathrm{hr}$ 篢 & 1 & 1.40 & 0.141 & 2.42 & 0.075 & 3.38 & 0.216 & 4.52 & 0.232 & 5.62 & 0.133 \\
\hline & $2 \mathrm{hr}$ & 1 & 1.33 & 0.151 & 2.35 & 0.055 & 3.38 & 0.214 & 4.48 & 0.133 & 5.58 & 0.130 \\
\hline & $3 \mathrm{hr}$ & 1 & 1.35 & 0.084 & 2.37 & 0.052 & 3.42 & 0.232 & 4.47 & 0.121 & 5.57 & 0.242 \\
\hline & $12 \mathrm{hr}$ & 1 & 1.38 & 0.117 & 2.35 & 0.011 & 3.37 & 0.082 & 4.35 & 0.122 & 5.57 & 0.151 \\
\hline & $24 \mathrm{hr}$ & $"$ & 1.38 & 0.117 & 2.43 & 0.103 & 3.42 & 0.117 & 4.37 & 0.103 & 5.55 & 0.152 \\
\hline
\end{tabular}

\begin{tabular}{|c|c|c|c|c|c|c|c|c|c|c|c|c|}
\hline \multirow{7}{*}{ 左. } & 前 & $\mathrm{ABR}$ & 1.33 & 0.103 & 2.35 & 0.084 & 3.35 & 0.055 & 4.40 & 0.063 & 5.57 & 0.103 \\
\hline & Irit 後 & $"$ & 1.33 & 0.103 & 2.35 & 0.084 & 3.38 & 0.041 & 4.38 & 0.075 & 5.60 & 0.126 \\
\hline & $\mathrm{l} \mathrm{hr}$ 嵝 & $"$ & 1.32 & 0.147 & 2.38 & 0.075 & 3.40 & 0.126 & 4.43 & 0.137 & 5.67 & 0.103 \\
\hline & $2 \mathrm{hr}$ & $"$ & 1.35 & 0.187 & 2.35 & 0.105 & $3.3 B$ & 0.16 & 4.42 & 0.133 & 5.56 & 0.134 \\
\hline & $3 \mathrm{hr}$ & $"$ & $1.3 B$ & 0.160 & 2.42 & 0.117 & 3.40 & 0.228 & 4.42 & 0.172 & 5.57 & 0.280 \\
\hline & $12 \mathrm{hr}$ & " & 1.43 & 0.151 & 2.40 & 0.141 & 3.38 & 0.147 & 4.35 & 0.105 & 5.57 & 0.121 \\
\hline & $24 \mathrm{hr}$ & $"$ & 1.38 & 0.075 & 2.37 & 0.082 & 3.40 & 0.126 & 4.37 & 0.103 & 5.56 & 0.167 \\
\hline
\end{tabular}


の減少, 胞体及び核の染色性並に形態学的変 化, 䯑道鞘では畽脹, 断裂及び崩壊, glia 細胞 では胞体及び核の染色性並に形態学的変化, 脸 室上皮では剶離等, 血管系では染色性並に形態
学的変化を示す．また，相当部位の一部に陽性 所見があるものは全て“十”とした。

1) 対照群

前庭神経系，蝸牛神経系及び顔面神経系等脳

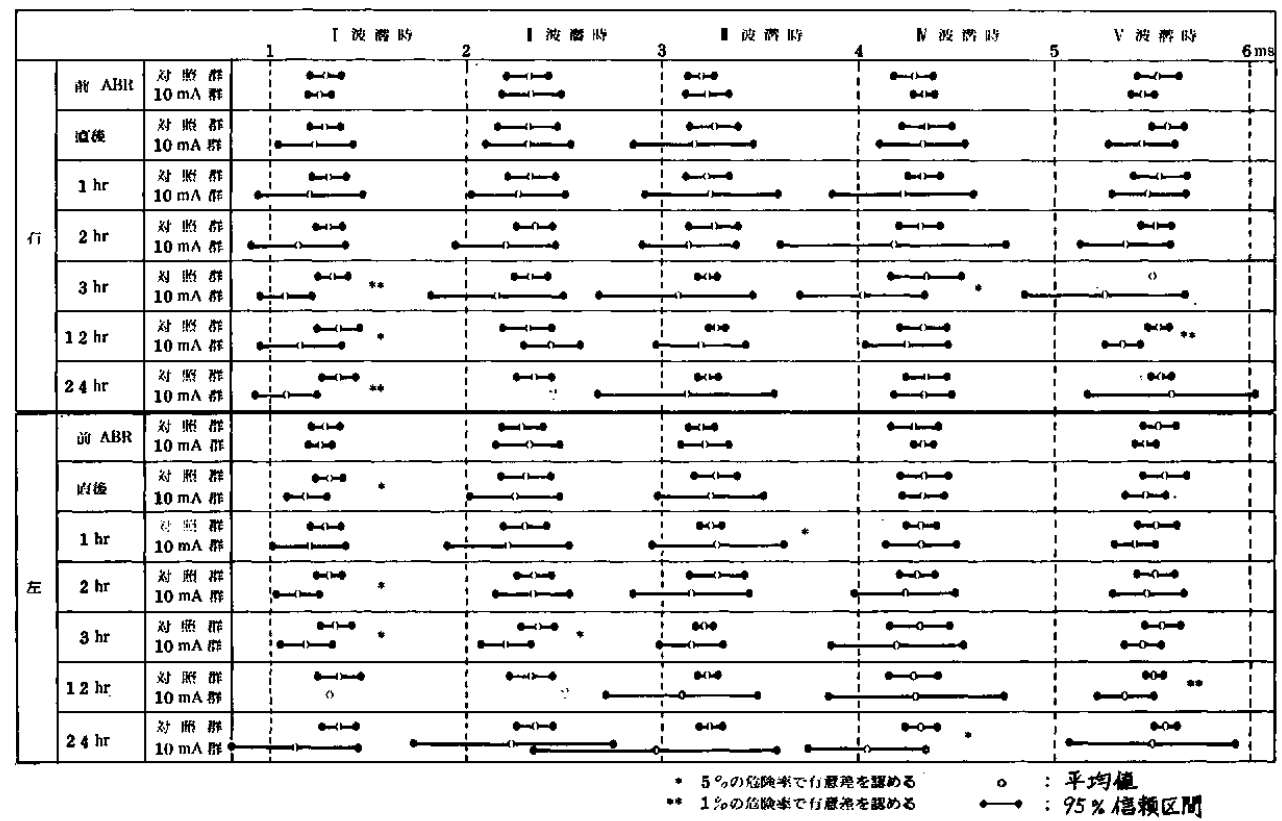

图 $810 \mathrm{~mA}$ 群と対照群A B R 各波潜時の各計測点における比較

\begin{tabular}{|c|c|c|c|c|c|c|c|}
\hline & & & I 没覀珠 & 1 设粦时 & I破恝㭙 & 'N 诐麾時 & V诐害时 \\
\hline \multirow{7}{*}{ fi } & 的 $\mathrm{ABR}$ & 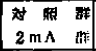 & $\leftrightarrow$ & $\leftrightarrow$ & $\infty$ & $\rightarrow$ & $\stackrel{\leftrightarrow}{\bullet}$ \\
\hline & 筧绕 & 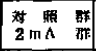 & $\underset{0}{\infty}$ & 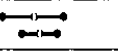 & $\because$ & $\rightleftarrows$ & $\Leftrightarrow$ \\
\hline & $1 \mathrm{hr}$ & 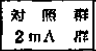 & $\because$ & $\because \rightarrow$ & $\because$ & $\stackrel{\operatorname{man}}{\longrightarrow}$ & $\Leftrightarrow$ \\
\hline & $2 \mathrm{hr}$ & $\begin{array}{|cc|}\text { 村 } \\
2 \mathrm{y}\end{array}$ & $\Leftrightarrow$ & 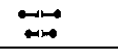 & $\stackrel{\leftrightarrow}{\rightleftarrows}$ & " & $\stackrel{\operatorname{mim}}{\rightarrow}$ \\
\hline & $3 \mathrm{hr}$ & 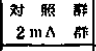 & $\rightarrow$ & $\rightarrow$ & $\stackrel{\infty}{\longrightarrow}$ & $\stackrel{\longrightarrow}{\longrightarrow}$ & $\stackrel{\circ}{\circ}$ \\
\hline & $12 \mathrm{hr}$. & $\begin{array}{|cc|}\text { 詨 } \\
2 \mathrm{~m} \\
2 \mathrm{~m} \wedge\end{array}$ & $\because$ & 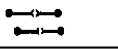 & $\because$ & מصستص: & مسته \\
\hline & $24 \mathrm{hr}$ & 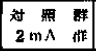 & . & $\because$ & مـ & $\because$ & $\stackrel{\infty}{\infty}$ \\
\hline \multirow{7}{*}{$\hbar$} & Ao $A B R$ & 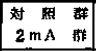 & $\Leftrightarrow$ & $\ddot{a}$ & an & $\rightarrow \rightarrow$ & $\underset{m}{\infty}$ \\
\hline & 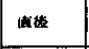 & 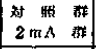 & 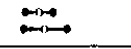 & $\leftrightarrow$ & 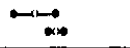 & 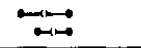 & $\Leftrightarrow$ \\
\hline & $1 \mathrm{hr}$ & 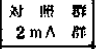 & $\leftrightarrow$ & $\rightarrow$ & $\because$ & $\because$ & $\stackrel{\leftrightarrow}{\leftrightarrow}$ \\
\hline & $2 \mathrm{hr}$ & 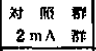 & $\stackrel{\longrightarrow}{\longrightarrow}$ & $\because n$ & $\leftrightarrow$ & $\because \rightarrow$ & $\stackrel{\leftrightarrow \rightarrow}{\leftrightarrow}$ \\
\hline & $3 \mathrm{hr}$ & 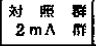 & $\stackrel{\rightarrow \infty}{\leftrightarrow}$ & $\Leftrightarrow$ & $\stackrel{+\infty}{\longrightarrow}$ & $\because$ & 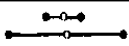 \\
\hline & $12 \mathrm{hr}$ & 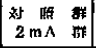 & $\stackrel{\leftrightarrow}{\leftrightarrow}$ & $\stackrel{\leftrightarrow}{\leftrightarrow}$ & $\stackrel{0}{\infty}$ & $\stackrel{\leftrightarrow}{\longrightarrow}$ & م \\
\hline & $24 \mathrm{hr}$ & 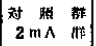 & $\rightarrow$ & $\underset{\infty}{\infty}$ & $\because$ & $\rightarrow$ & $\stackrel{-\infty}{\rightarrow \infty}$ \\
\hline
\end{tabular}

図 $92 \mathrm{~m}$ A 群と対照群A B R 各波潜時の各計測点における比較 
右工波燳時
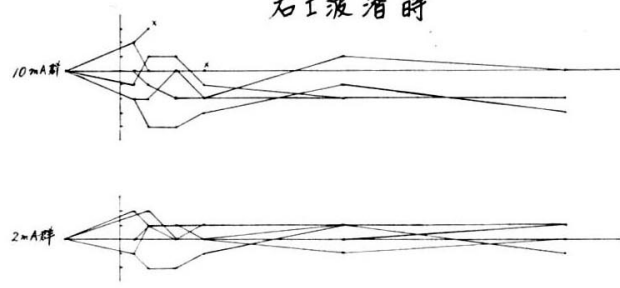

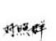

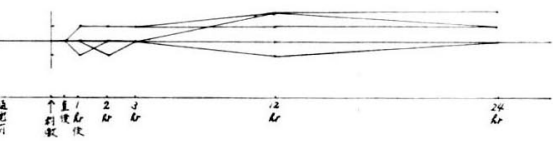

右正波潜時
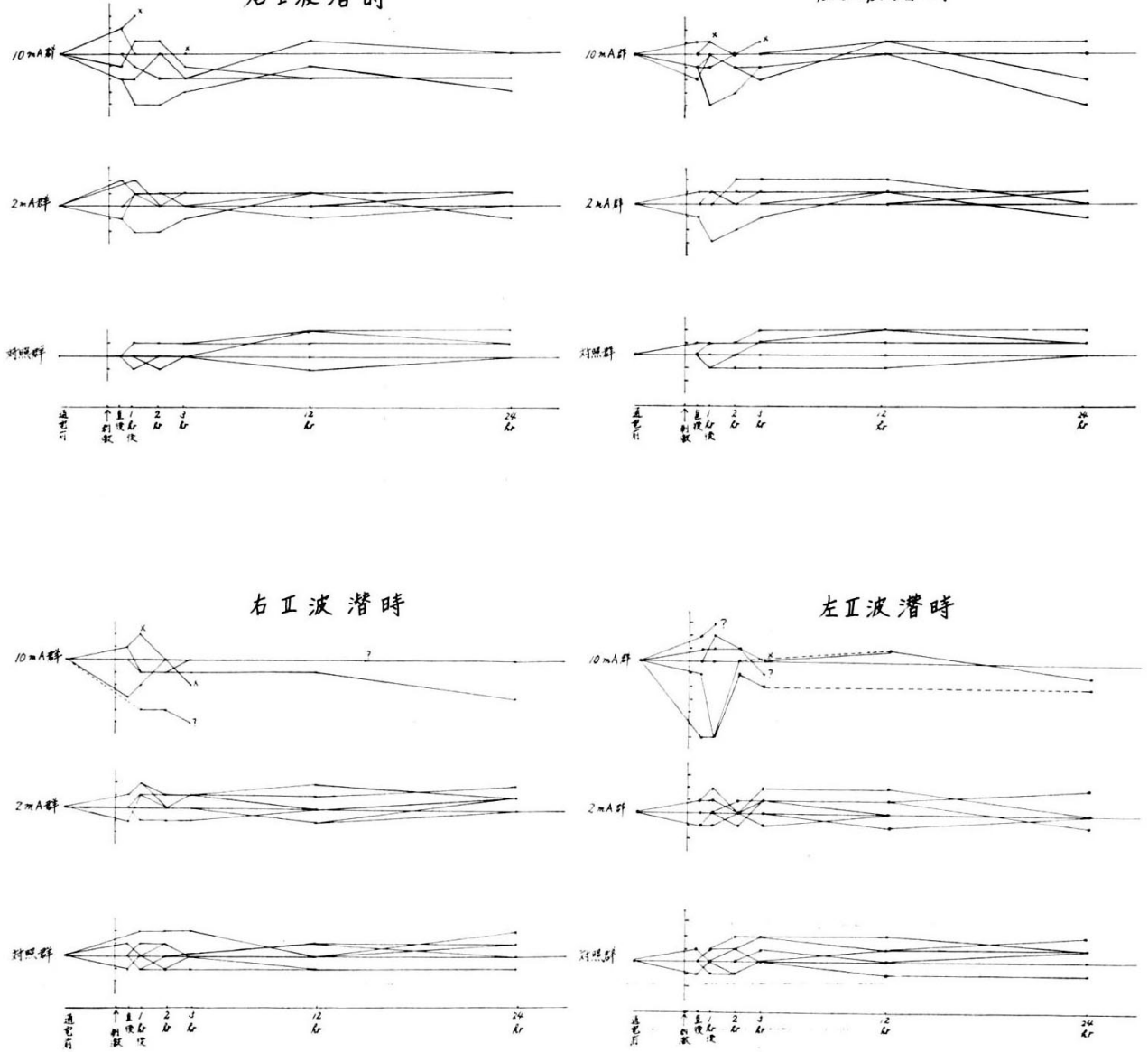

左工波潜時

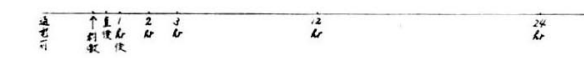
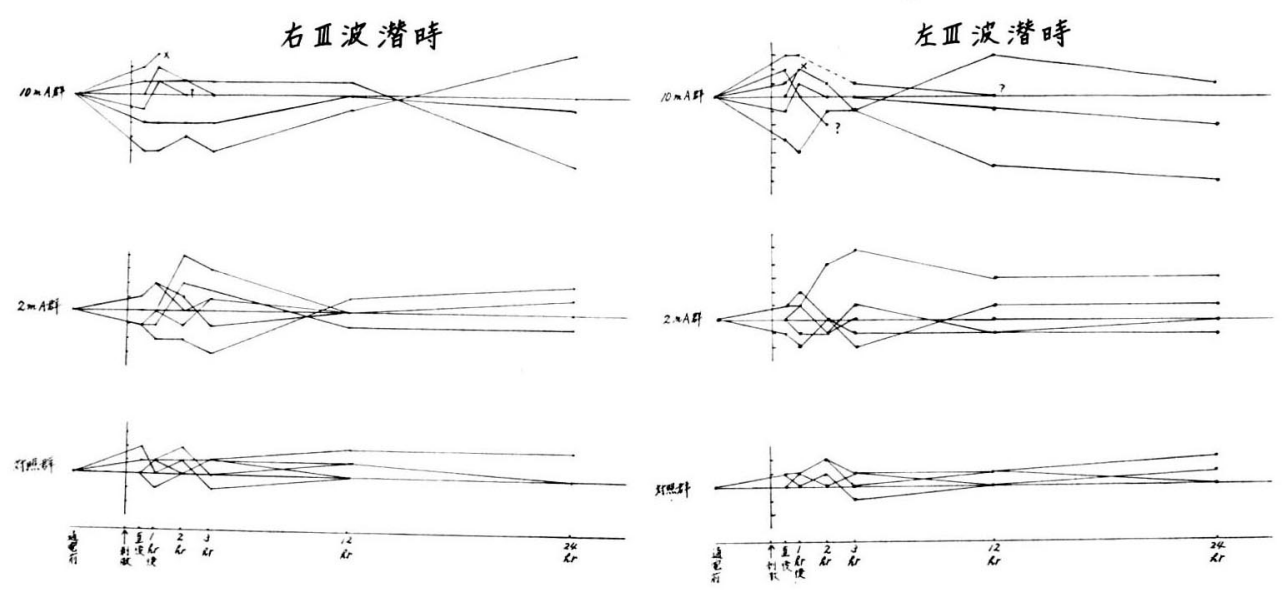

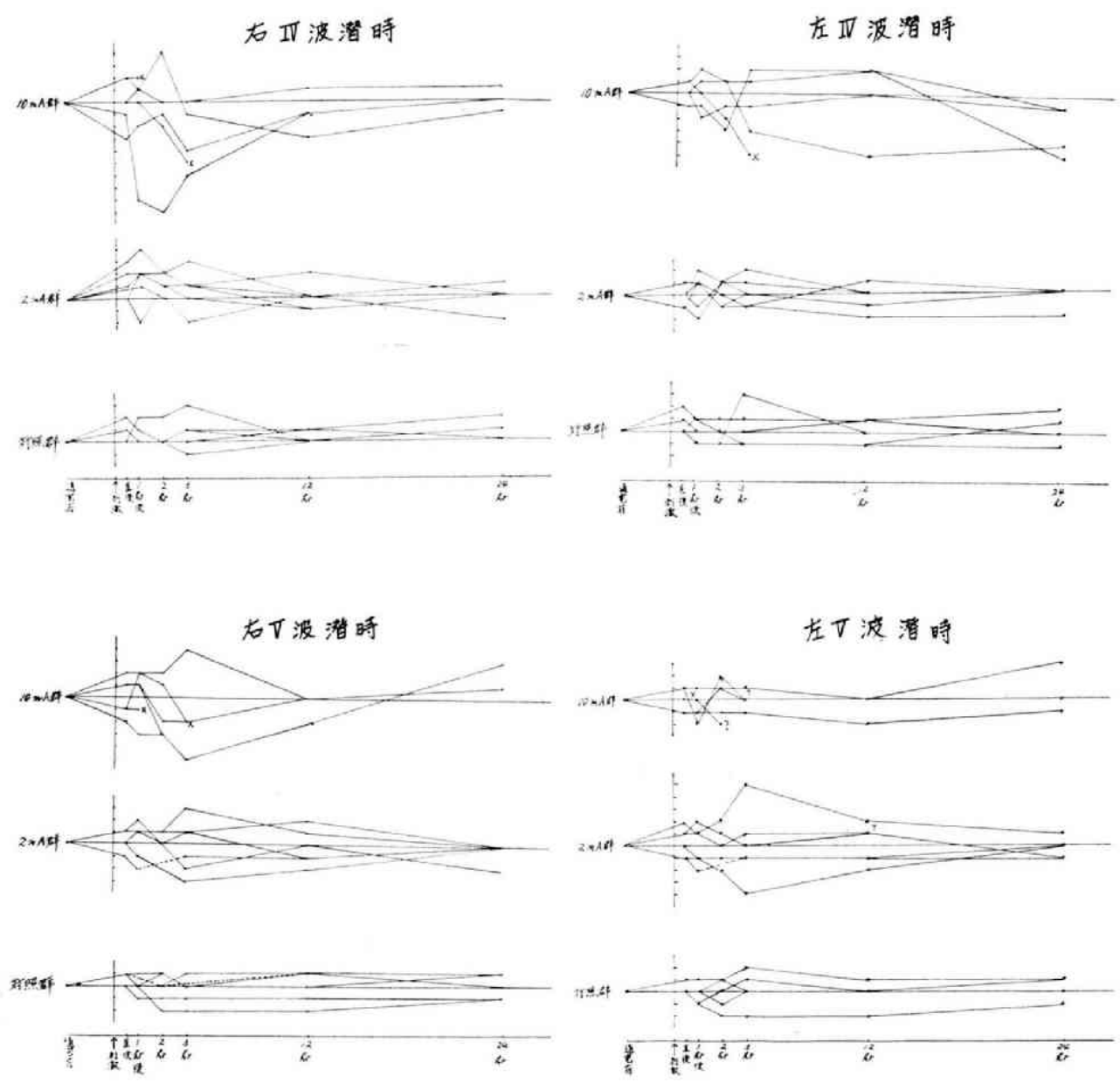

$\times$ : 死亡 ? : 波形消失

$\cdots$ : 途中波形消夫

図10 10m A 群, $2 \mathrm{~m}$ A 群並びに対照群間の各波潜時の変化量の比較 (各動物の通電前各波潜時を原点とする)

幹部並に設置した電極直下の大脳には，とくに 変化はなかった. 対照群病理組織学的所見は, ネンブタール麻酔下の電極設置及び72時間の時 間経過では，著明な変化がないと結論する。

\section{2) $10 \mathrm{~mA}$ 群}

病理組織学的検索の結果, №.202加ら №.205に 陽性所見を認めた。共通して陽性所見を認めた のは右側の medial vestibular nucleus(MVN), ventral cochlear nucleus(VCN) 及び ependymal cell of cerebral aqueduct である.
最も障害籁囲が広く，しかも左右差も明碓で ある №.205 の病理組織学的所見を代表として呈 示し, 詳述する.

下丘交連レベルのHE染色 (図11), Nissl 染 色 (図12,13) 及び Klüver and Barrera 染色 （図14，15）及び Bodian 染色（図16）を示す.

$\mathrm{HE}$ 染色では, 中脳水道右側の central gray matter, 右 inferior colliculus (IC) の表層之 樑層, 右 commissure of inferior colliculus (CIC), 右 lateral lemniscus (LL) 及び右 
medial longitudinal fasciculus (MLF) を中 心にエオジンに濃染する部分を認める。即ち二 ューロンの胞体は好酸性に均質に染まり腫胀 し，核はとくに偏化はないが好塩基性に染まる
か淡染している，また一部核は濃㗱し，胞体は 萎紡し紐長い屯のもある，納胞間組織もエオジ ンに溦染している，大食紐胞は認めない。この レベルではさらに散在性に血管系に括いて血管

表 6 脳幹部病理組織学的検索の成績

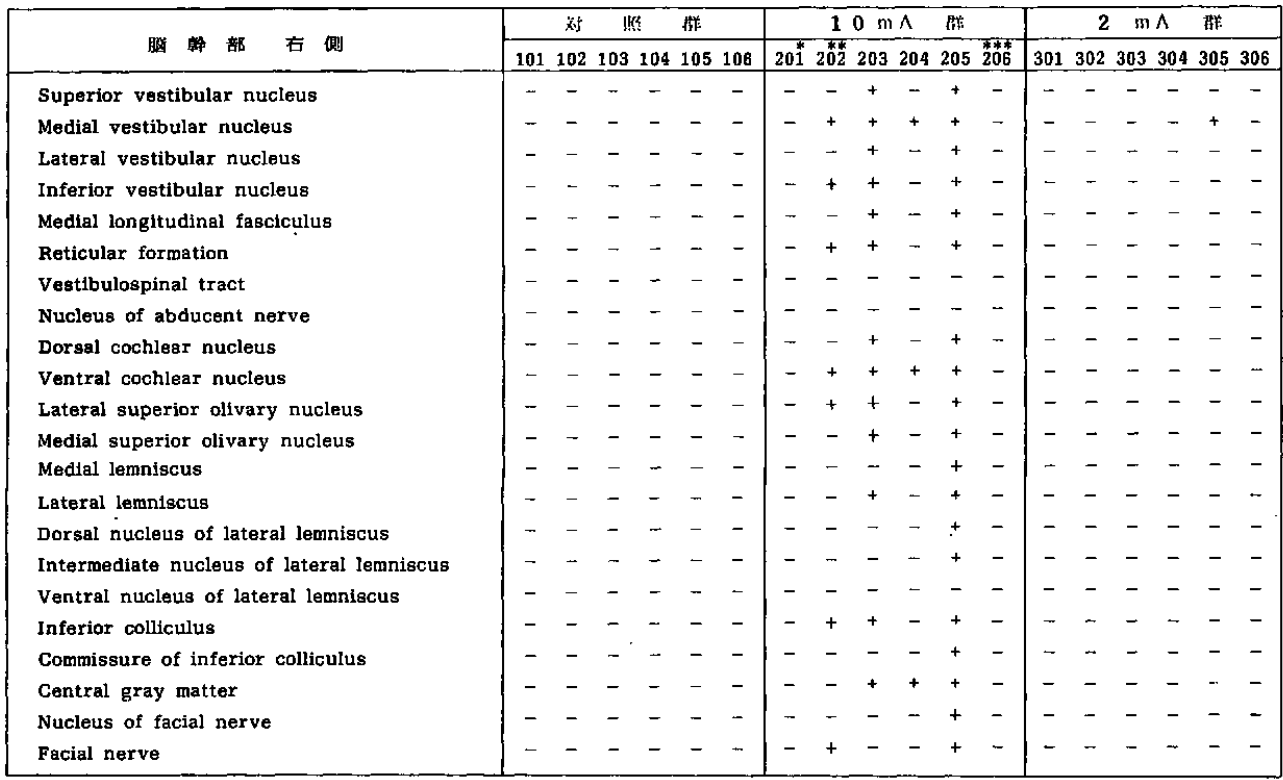

\begin{tabular}{|c|c|c|c|c|c|c|c|c|c|c|c|c|c|c|c|c|c|c|}
\hline \multirow{2}{*}{ 媨 翰激 \%: 側 } & \multicolumn{2}{|r|}{ 好 } & & & \multicolumn{6}{|c|}{$10 \mathrm{~mA}$ 群 } & \multicolumn{4}{|c|}{$2 \mathrm{~mA}$} & \multicolumn{2}{|l|}{ 群 } \\
\hline & 101 & 102 & 103 & 104 & 105 & 106 & 201 & 202 & 203 & 204 & 205 & 206 & 301 & 302 & 303 & 304 & 305 & 306 \\
\hline Superior vestibular nucleus & - & - & - & - & - & - & - & - & - & - & - & - & - & - & - & - & - & - \\
\hline Medial vestibular nucleus & - & - & - & - & - & - & - & - & - & - & - & - & - & - & - & - & - & - \\
\hline Lateral vestibular nucleus & - & - & - & - & - & - & - & - & - & - & - & - & - & - & - & - & - & - \\
\hline Inferior vestibular nucleus & - & - & - & - & - & - & - & - & - & - & - & - & - & - & - & - & - & - \\
\hline Medial longitudinal fasciculus & - & - & - & - & - & - & - & - & - & - & + & - & - & - & - & - & - & - \\
\hline Reticular formation & - & - & - & - & - & - & - & + & - & - & + & - & - & - & - & - & - & - \\
\hline Vestibulospinal tract & - & - & - & - & - & - & - & - & - & - & - & - & - & - & - & - & - & - \\
\hline Nucleus of abducent nerve & - & - & - & - & - & - & - & - & - & - & - & - & - & - & - & - & - & - \\
\hline Dorsal cochlear nucleus & - & - & - & - & - & - & - & - & - & - & - & - & - & - & - & - & - & - \\
\hline Ventral cochlear nucleus & - & - & - & - & - & - & - & - & - & - & - & $\rightarrow$ & - & - & - & - & - & - \\
\hline Lateral superior olivary nucleus & - & - & - & - & - & - & - & - & - & - & - & - & - & - & - & - & - & - \\
\hline Medial superior olivary nucleus & - & - & - & - & - & - & - & - & - & - & + & - & - & - & - & - & - & - \\
\hline Medial lemniscus & - & - & - & - & - & - & - & + & - & - & + & - & - & - & - & - & - & - \\
\hline Lateral lemniscus & - & - & - & - & - & - & - & - & - & - & - & - & - & - & - & - & - & $*$ \\
\hline Dorsal nucleus of lateral lemniscus & - & - & - & - & - & - & - & - & - & - & - & - & - & - & - & - & - & - \\
\hline Intermediate nucleus of lateral lemniscus & - & - & - & - & - & - & - & - & - & - & - & - & - & - & - & - & - & - \\
\hline Ventral nucleus of lateral lemniscus & - & - & - & - & - & - & - & - & - & - & - & - & - & - & - & - & - & $\therefore$ \\
\hline Inferior colliculus & - & - & - & - & - & - & - & - & - & - & + & - & - & - & - & - & - & - \\
\hline Commissure of inferior colliculus & - & - & - & - & - & - & - & - & - & - & + & - & - & - & - & - & - & - \\
\hline Central gray matter & - & - & - & - & - & - & - & - & - & - & + & - & - & - & - & - & - & - \\
\hline Nucleus of facial nerve & - & - & - & - & - & - & - & - & - & - & - & - & - & - & - & - & - & - \\
\hline Facial nerve & - & - & - & - & - & - & - & - & - & - & - & - & - & - & - & - & - & - \\
\hline
\end{tabular}

十：障害あり

$* 4$ 時閣後死亡時固定
一：障害なし

**30時開後死亡時固定
*** 1 時䦩後死亡後固定 
内皮は剶離し，血管周囲はエオジンに濃染して いるすのが一部珰められる. また ependyma の脱落及び上衣紐胞の核の濃縮及び胞体の萎縮 が一部認められる，またこれら所見は左側は軽 度であり明らかに左右差を認める．Nissl 染色

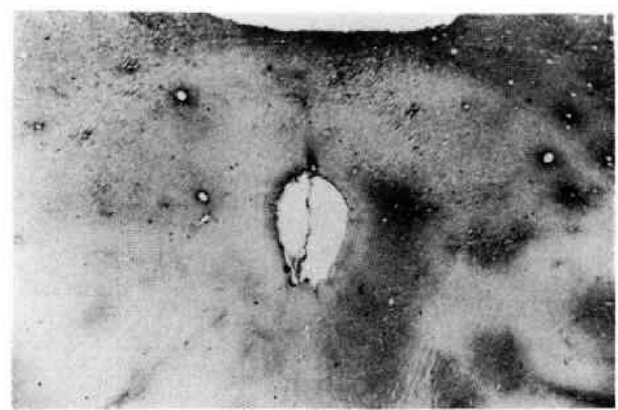

図II 下丘交連を認めるレベルのHE染色 中心灰白質（右側）及び下丘並に下丘交連にエ オジンに濃染する部を認める
では, 同部に Nissl 小体の減少, 消失, 及び 一部核の崩壊が热められ，また細胞間隙の拢大 を認める. Klüver and Barrera 染色では, 同 部は淡染し，䯣鞘の腫脹，断裂及び一部崩壊を 認める。

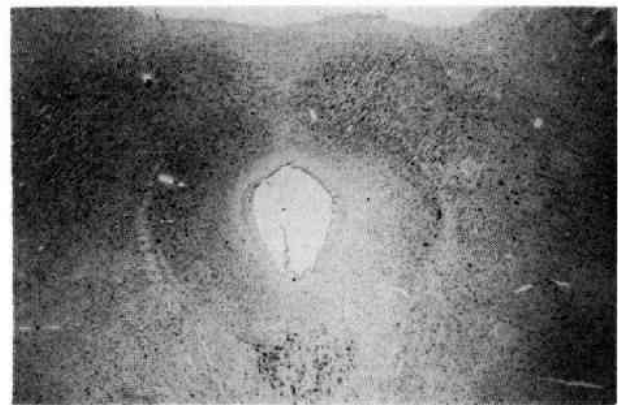

図12 下丘交連を慧めるレペルの Nissl 染色 右側中心灭白質を中心に焁染しているのが琶め られる。

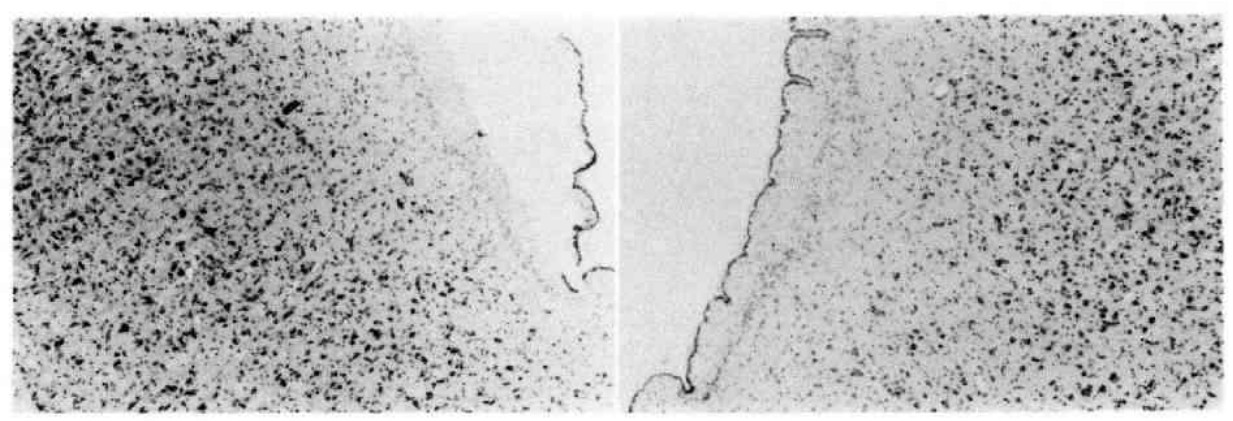

図13 中脳水道及びその周囲の拡大図 (Nissl 染色)

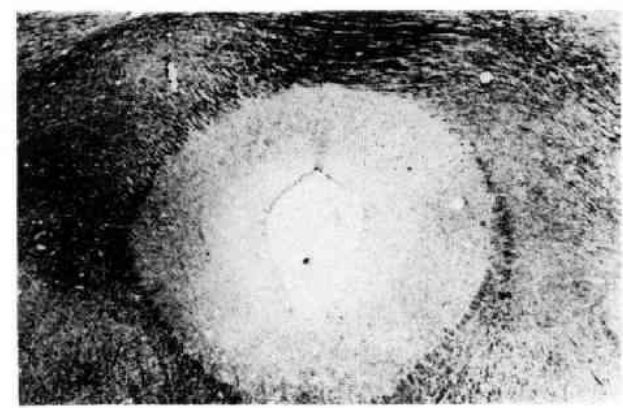

図14 下丘父連を琶めるレベルの Klüver and Barrera 染色 

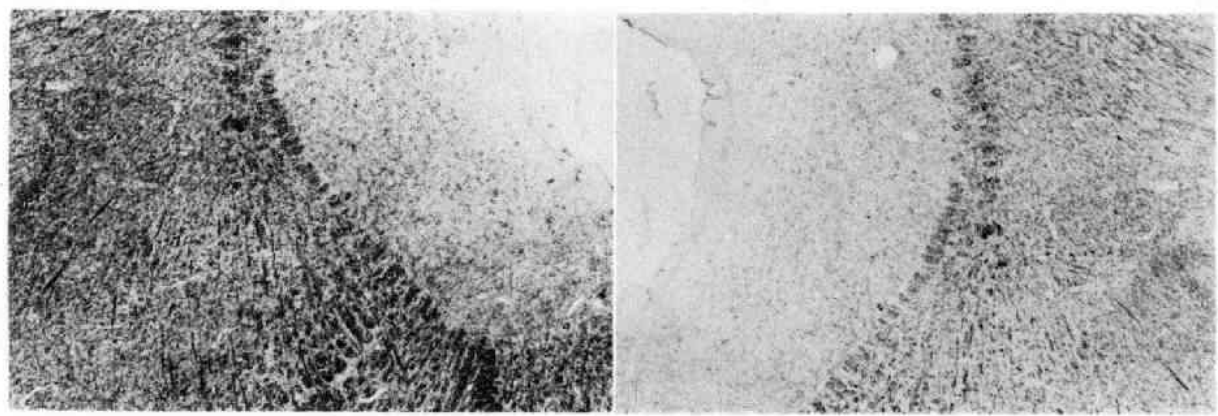

図15 中脸水道及びその周囲の拡大図 (Klüver and Barrera 染色)

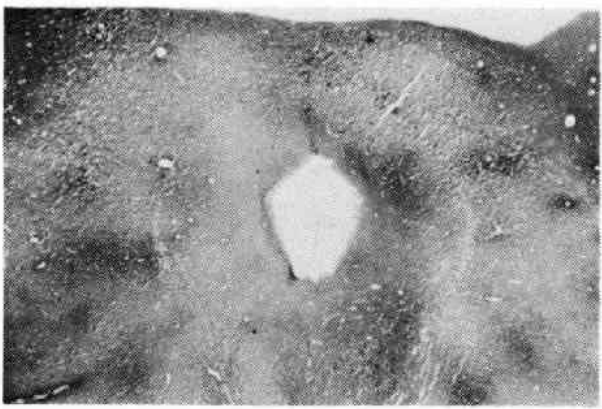

図16 下丘交連を認めるレペルの Bodian 染色 中心扊白質 (右側)，下丘及び下丘交連を中心 に濃染する部を認める

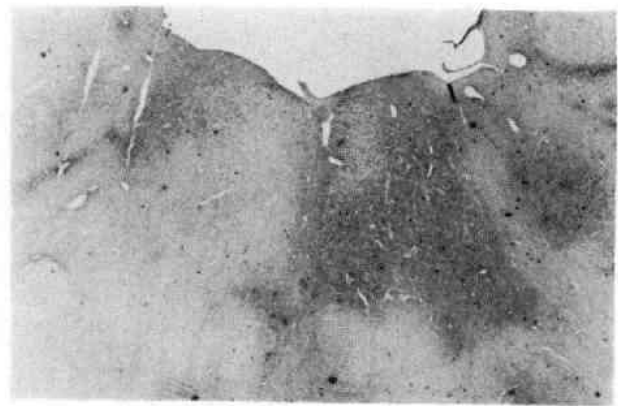

図17 橋レベルのH E染色

特に右側の脳幹網様体及び内側縦束を中心にェ オジンに濃染に濃染する部を羿める
Bodian 染色では，上記部位に一致して，神 経線維の膨化を認めるが, 断裂は認めない. 上 記の諸变化 (壊死像) には, 健常部む混在して いる.

橋レベルのHE染色（図17, 18), Nissl 染色 (図19，20), Klüver and Barrera 染色（図21, 22) 及び Bodian 染色 (図23，24）走示す. 橋に おいて HE 染色では, 左右 reticular formation (RF), 左右 vestibular nuclei 群, 左右 $\mathrm{ML}$ $\mathrm{F}$, 右 cochlear nuclei 群, 右 superior olivary nucleus (SOC), 右 nucleus of abducent nerve (NAN), 右ML, 右 facial nerve (FN) 及び nucleus of facial nerve (NFN) に, エオジン に濃染する部分を認める。神経細胞の胞体は好 酸性に腫脹し，核は淡染する，また細胞間組織 はエオジンに滥染している。 そしててれらの変

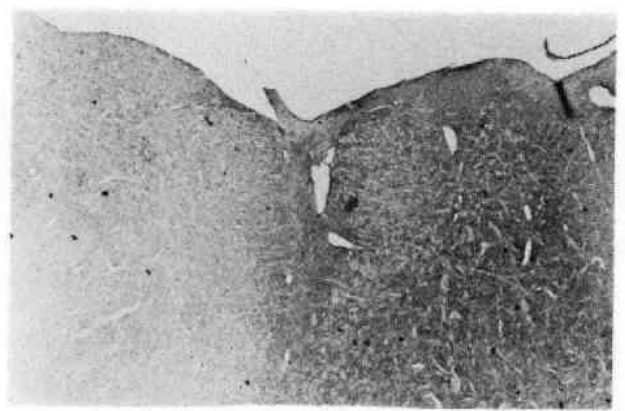

図18 内側縦束及び脳幹網樣体 (H E 染色) 


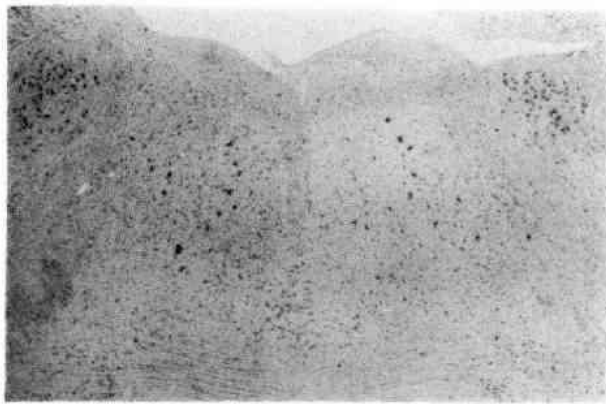

図19 橋レベルの Nissl 染色 右側の脳幹網様体及び内側縦束を中心に淡染 しているのが認められる.

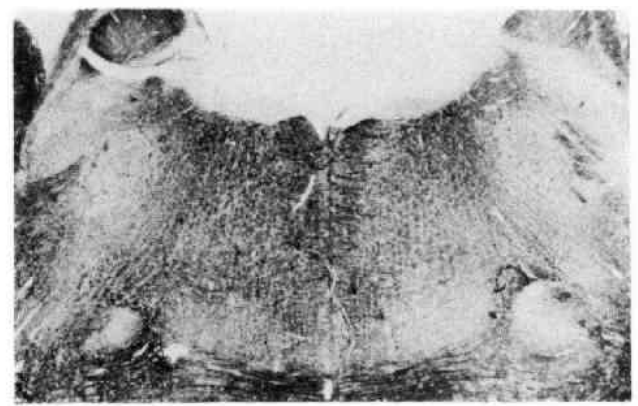

図21 橋レベルの Klüver and Barrera 染色 特に右側の脳幹網様体, 内側綐束及び上オリ一 ブ核周囲か淡染しているのが認められる.

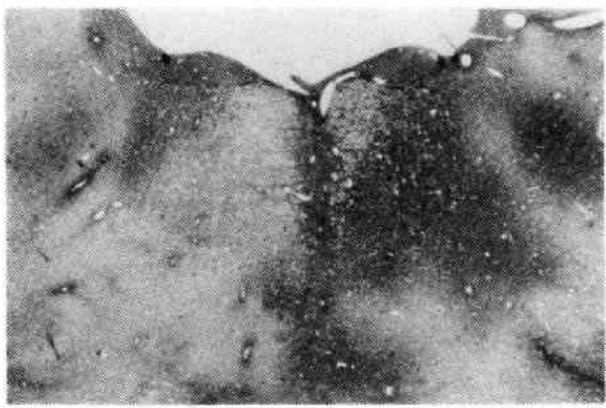

図23橋レベルの Bodian 染色

化は，左側では範囲及び程度が軽く明らかに左 右差を認める. Nissl 染色では, 同部に Nissl 小体の減少, 消失, 及び一部核の崩壊, 及び, 組織間隙の拡大を認める. Klüver and Barrera

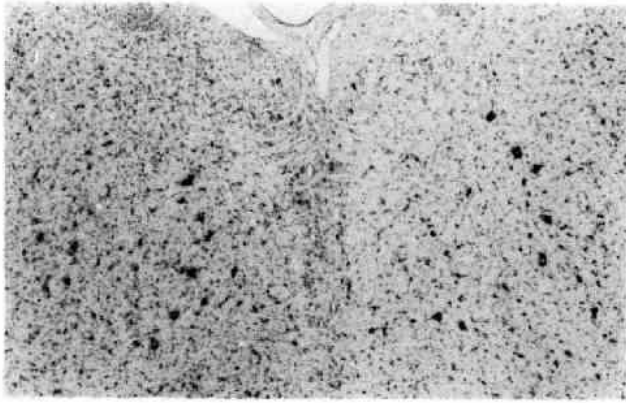

図20 内側縦束及び脳幹網様体 (Nissl 染色)

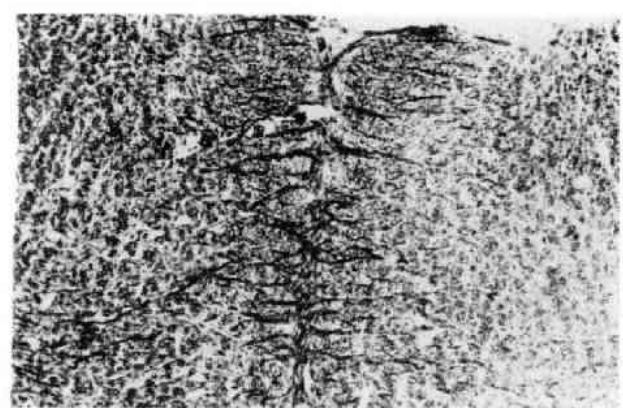

図22 内側縌束及び脳幹網樣体 (Klüver and Barrera 染色)

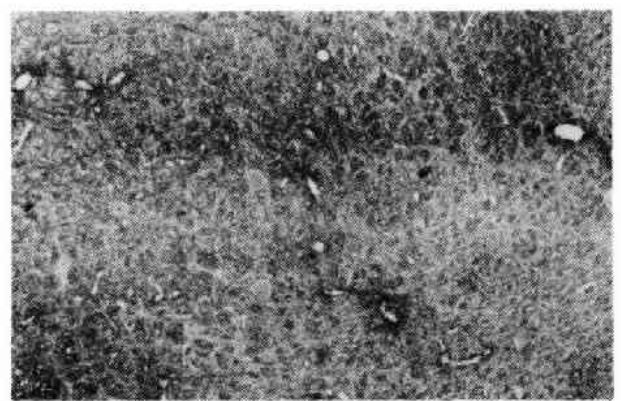

図24 右内側綐束及び右脳幹網様体 (Bodian 染色) 諸変化 (壞死像) と健常部の混在が認められる

染色では，同部は淡染し，䯣鞘の腫脹，断裂及 び一部崩壊を認める，走行異常は認めない，

Bodian 染色では, 神経細胞の脱落は認めな いが，胞体は若干繥化し，胞体自体は均一に染 
仙さ扎ている。核の変化はとくに綛めないが，

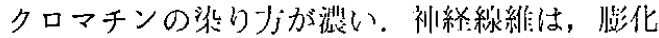
を諗めるが，断裂は誌めない，尘行異常は認め ないまたこれら諸変化（㘺死像）上健常部の 混在が認められる。

このレベルに招いて，障㫪の笵囲及び程度は 前庭神経系蝸牛神経系>顔西神経系の順で強 い.

\section{3) $2 \mathrm{~mA}$ 群}

6 例听 1 例（N.305）のみ，陽性所少を冨め た。内容は，右MVNの Nissl 小体の紫度の渽 少，及び第 4 脳室底通雪侧上衣細胞の胞体の瘘 縮である。

4) 小括

陽性所罗を示した部仙をまとめ再粠成し，网 25に示す．橋レベルより下.斤交連を認めるレべ ルにわたって左右善のある変化を認めた。そその 陽性所見は Nissl 小体の減少及び消失, 核の 染色性並に北態の変化, 神経線維の变化, 能道鞴

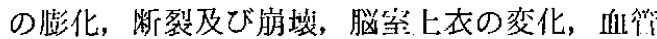

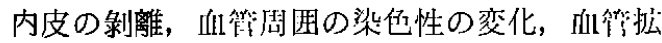
張及び組織間隙の桩大である.

$10 \mathrm{~mA} 20$ 分間通電の媭合，牛ずる脳翰部への

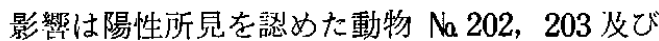
205 亿拈いては非可逆性の変化を含むと考え る.

また $2 \mathrm{~mA}$ 群においては，陽性所志を滺めた のは 6 例中 1 例であり，この程度の通䨪では， 病理組織学的にはほとんど変化を起さないもの と若える.

次に右侧頚弇乳笑部三何一䫓頂問に $10 \mathrm{~mA} 20$ 分間定電流通電を行った曙令の雷流の流れを， 病理組織学的所光より検徑する。1脳水道より 第 4 脳䇪底の特に通電側の.上衣紒胞，上衣下间 の変化があり，その間国組織に変化が広がって いるとと及び右 I C 表们，CＩＣ及び右ＬＬに 所见を認め，その程度は表既に近いjが強いこ とより，電流の第 1 の䋂路は，跶液系または能 液严とこれに颃する脳幹部の表高を介したと考 える、また，下斥レベルより橋レベルまでの，

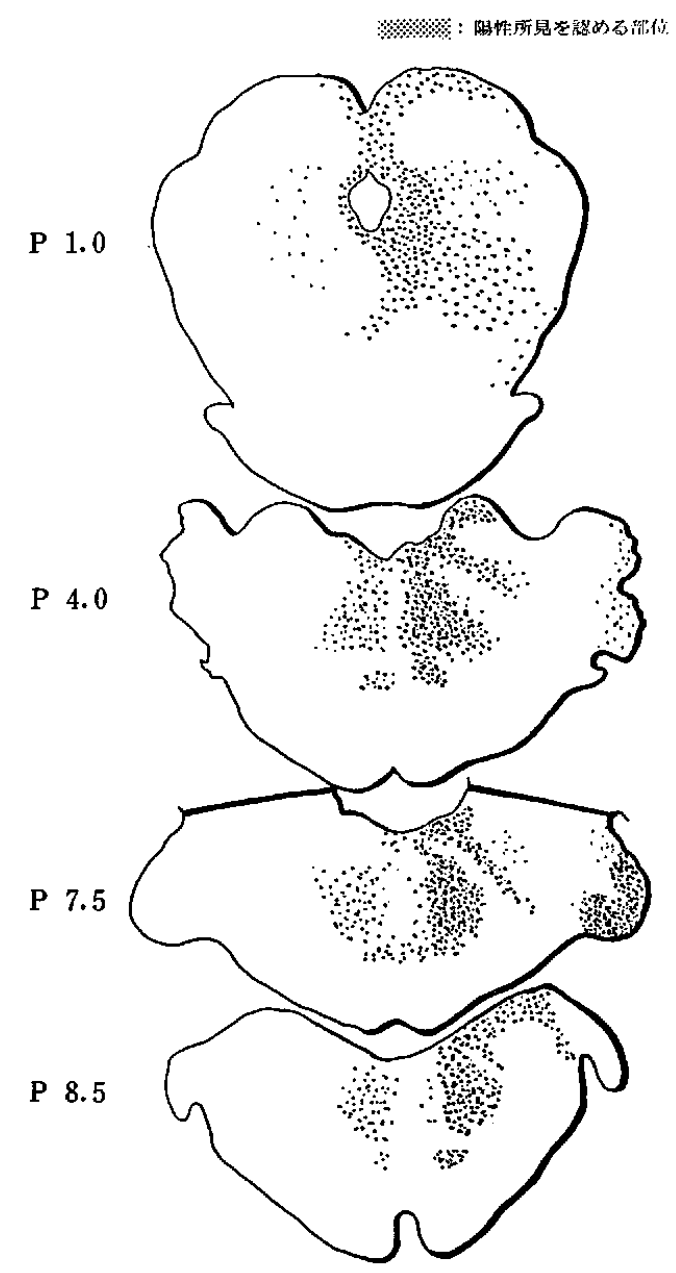

図25陽性所芫を示す部位の再構図

(Number は Snider-Niemer, 1961 による)

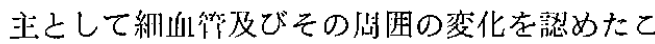
とにより，第 2 の経路は，臫管系を介したと考 える。しかしながら一うで，右前庭神経核群， 在蝸牛神経核群，左右 S O C 及び，下丘レベル から橋レベルまで広く左右 R F，左右M L F 及 び右 L Lに所迄を認めたとと，及び左右着を認 めたことは，视経伝筞路を介した第 3 の経路を 溞く示唆する。また陽性所見の出现頻度並に障 皆の程度より，前庭补経系蝸牛种経系>顔而 视経系の倾に雱流が多く流れたのではないかと 推测する。 
図26亿前庭神経伝薄路之諸け枢 ${ }^{20)}$ 亿おりる陽 性所罗を認める部位を示す。通電側の前庭神経 核群, MLF及びR F 並に反側の R F 及び ML Fの一部に陽性所見を認める。

図27に蝸牛神経系伝等路と諸中枢 ${ }^{211}$ における
陽性所㫕を弪める部估を示す，通電側の螖牛神

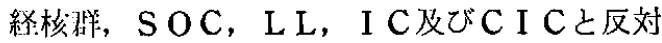
俶のS OC，I C及びC I Cの一部に陽性所見 を䜑める。

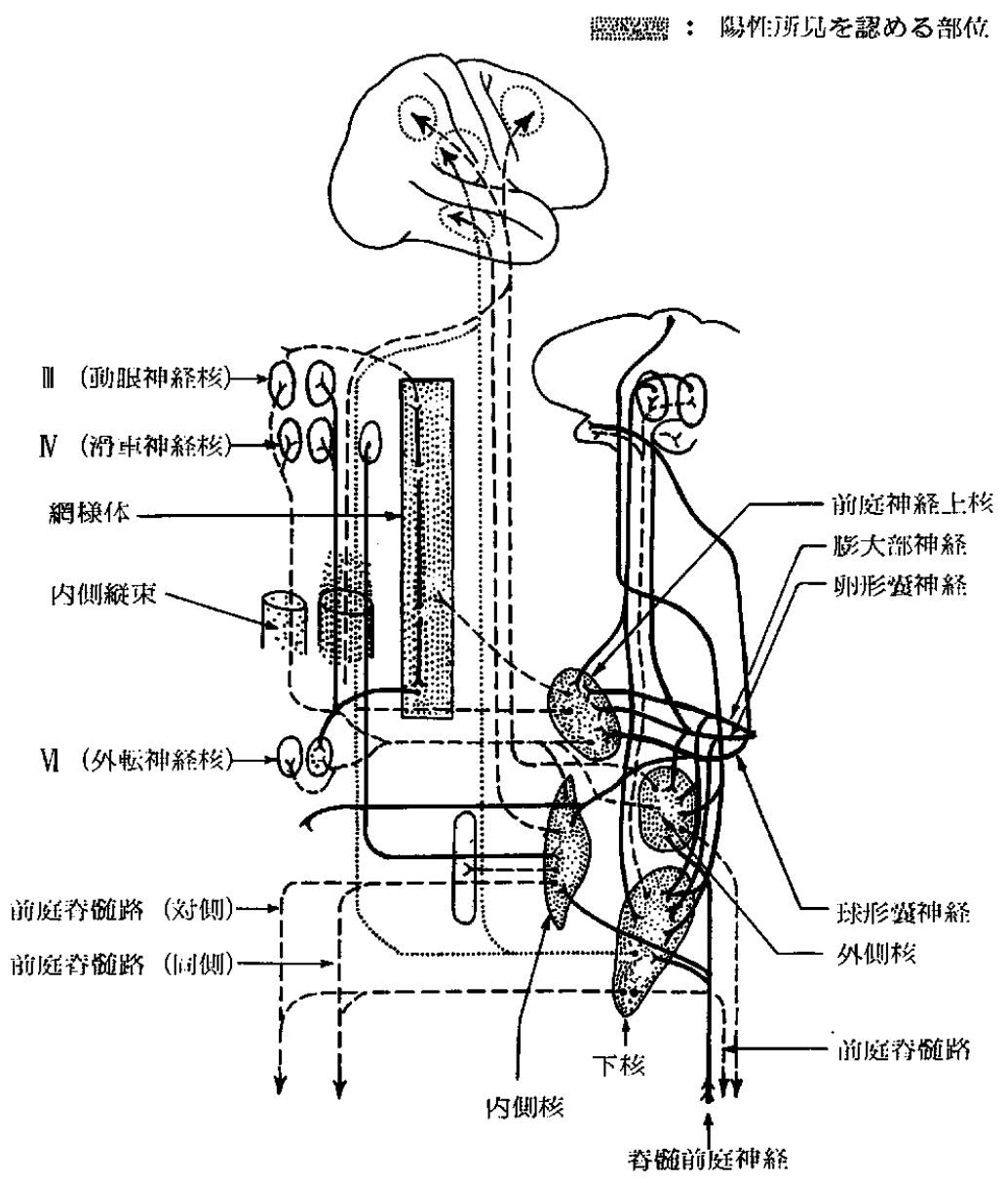

図26 前庭神経层導路と諸中枢における陽性所見を認める部位の模式図

(Boasy's Atlas of Neuroanatomy, 1970 改変) 
Auditory Cortex

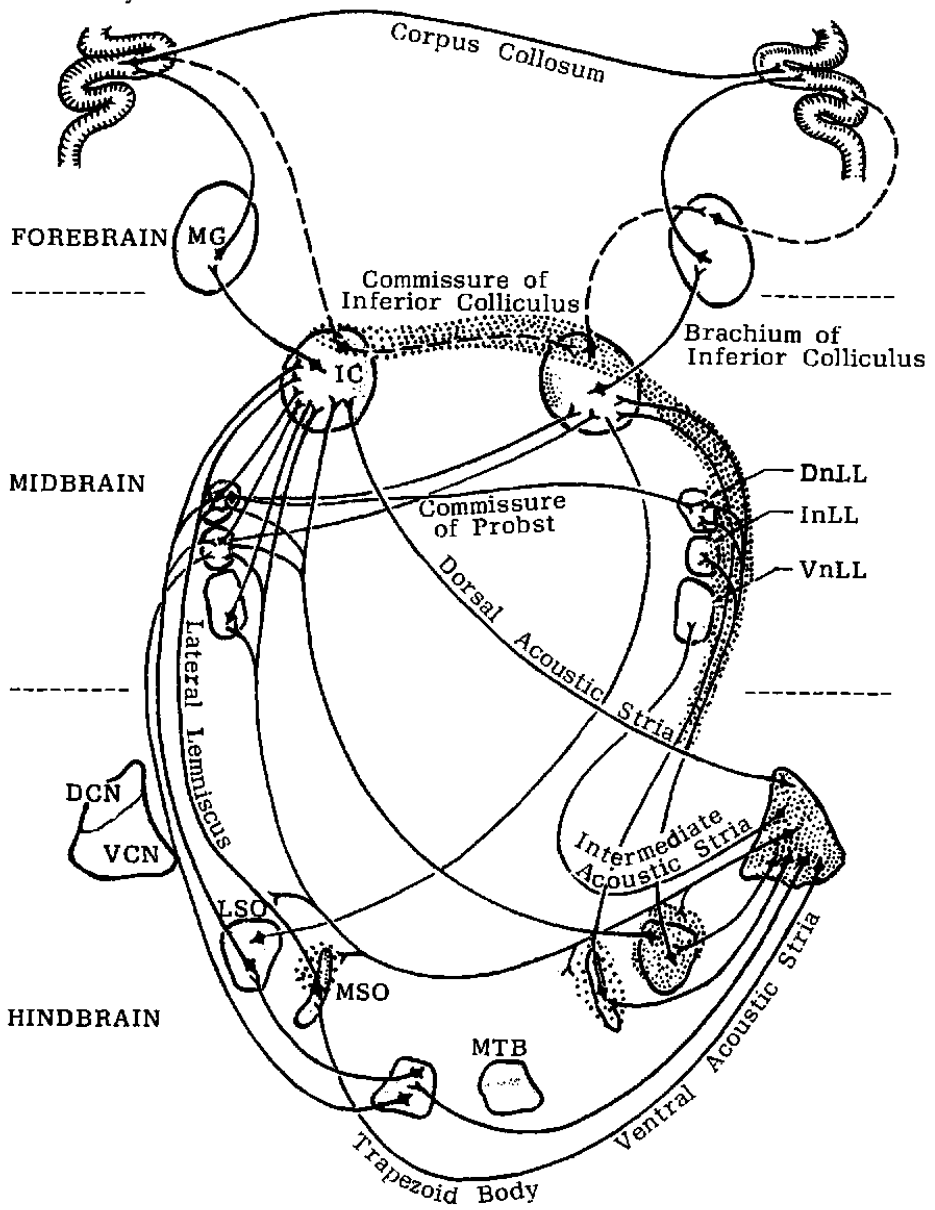

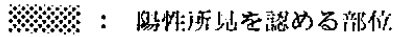

MG: Medial Geniculate（队优傣状沾）

IC: Inferior Colliculus ( $\vdash$. r.

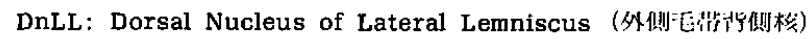

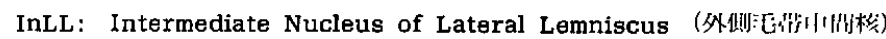

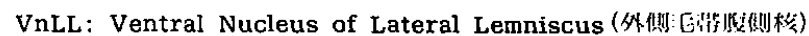

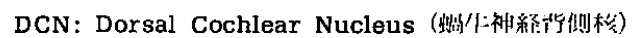

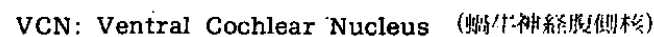

LSO: Lateral Superior Olive (外侧けナリーブ核)

MSO: Medial Superior Olive (队供ヒオリーブ格)

MTB: Medial Nucleus of the Trapezoid Body (fi)仅体以側格)

図27 螖牛神経伝導路と諸中枢における陽性所見を認める部位の模式図 (Thompson, Structure and function of the central auditory system, 1983 t改変) 
考

頭部殊に側頭部通電刺激により異常な生体反 応，例えば電気性身体動摇反応及び電気性眼反 応，が誘発されるととは 1792年 Volta が隹筧 し報告している，その後，Purkinje（1820）, Hitzig (1871)，さらに多くの基礎的並に臨床 的研究が報告されている．乙れらの研究の臨床 応用として, 所謂 Galvanic test が, 前庭機 能検査法に加えられてきた。 そして臨床経験上 加ら，本法が，迷路性・後迷路性疾患の鑑別診 断に役立つととが明らかにされた。しかしな 招，Galvanic test は，負荷刺激の作用部位， 誘発反応の発現機序について未だ解明されてい ない点がある。

負荷刺激の作用部位を動物実験で解明する方 法として；1）通常使用電流量・時間に比較し て大きな負荷を行い，病理組織学的検索を行う 方法 ${ }^{22) 299} ， 2$ ）組織の破塧あるいは神経切断 実験 ${ }^{23}$ 30)33)，3）薬物実験，4）負荷刺激に よる誘発電位の変化を細胞外誘導で記録する 方法 ${ }^{32)} ， 5$ ）通電刺激に他刺激を併用する力 法 ${ }^{33) 34)}$ ，及び 6 ）通電刺激結果を電気性眼反応 あるいは電気性身体動摇反応を用い判定する方 法35)・37)等が報告されている.

本実験はとの 1 つして，1）の方法を採用 し, unipolar test を用いた病理組織学的検索 を指標とした，著者の研究公では，儖床的に unipolar test 並に単極両耳”法 (double galvanic test)を採用し，後迷路疾患の鑑別診断，さらに 患側の決定に有力な判定基準を得ており ての作用部位解明を目的と考えたからである。

一方，1）に関する報告のうち南 ${ }^{22) 23}$ (1930) 小田 ${ }^{24) 28)}(1929)$ 小幡 $^{27)}{ }^{28)}(1953)$ 及び上塚 ${ }^{29)}$

（1966）は，全て両耳両極法を採用し，動物実 験を行っている，ての理由は，両耳両極法が最 あ少いあるいは弱い通電量で反応が得られると と，及び副作用が最む少ないととなどにより臨 床的に一般に推奖されている方法" であるとと によると推測する．従って本実験と相違する部

\section{枽}

分ああるが，概説すると：南はモルモット及び 家鬼を用い，20及び $100 \mathrm{~mA}$ を3 分加ら30分間 通電刺激し, 中耳, 内耳神経終末, 内耳神経組 織, 蝸牛神経核群, S O C, 台形体核, 前庭神 経核群，顔面神経系及びNANに陽性所見を観 察し，さらに極性により病理組織学的所見が異 なること及び24時間後において炎症性変化に移 行するてとを報告している，また南は，報告 中，モルモットの脳幹部に陽性所見を認める一 方, 家兔の, 前庭神経系に陽性所見を認めなか ったことにより，前庭神経系中枢は，電気性眼 反応に直接関与しないと結論している，小田は モルモット，家鬼及び猫を用い， $4 \mathrm{~mA}$ から50 $\mathrm{mA}$ を15分間ないし16時間通電刺激し，内耳神 経終末部では病理組織学的変化は前庭及び半規 管に限局しているとと，内耳神経組織は，ラセ ン神経節及び前庭神経節とすに陽性所見を示す ことを観察している．さらに所見は陰極側に強 いとと及び通電直後に強いことを報告してい る。小幡はモルモットを用い, $7 \mathrm{~mA}$ から 30 $\mathrm{mA}$ を数秒加ら 60 分間通電し内耳神経終末, 内 耳神経組織に陽性所見を観察し，報告してい る.上塚はモルモット及び家兔を用い, $100 \mathrm{~mA}$ 及び $250 \mathrm{~mA}$ を 30 秒加ら 10 分通電刺激し，内 耳神経終末及び内耳神経組織に陽性所見を観察 し，さらに極性により所見が異ること及び時間 経過に従って回復するてとを報告している。

南の報告之今回の成績を比較する，著者の猫 の橋レベルでは，RF，MLF，MLに陽性所 見を認め, 髄鞘の腫脤, 断裂, 崩壊, 血管内皮 及び血管周囲の変化，上衣細胞及び上衣の変化 を認めるが，南のモルモットではこれを認めな い。また南が報告したモルモット及び著者の猫 の両動物に共通して認めら机た部位において 屯, 前庭神経核群の Nissl 小体の消失, 核の崩 壊等, 陽性所見の程度が異なる。乙れら所見が 異なることは，南が bipolar test を用い両外耳 道内に電極を設置しているのに対し著者は， 
unipolar test を用い側頭骨乳实三角及び頭頂骨 の骨内に電極を設置したことによる相違等によ る影響加と考える。

一般に臨床的に接触事故で電気エネルギーが 中枢神経系に作用した場合, Peters ${ }^{38)}$ は,

(1) 発熱生

(2) 直接的作用

(3) 間接的作用 (二次的循環障害)

(4) 外傷による作用 (転落等)

(5) 全身状態に上る変化 (火傷等)

を分類している，そして低電圧電気に接触した 場合，とくに第 3 脳室，中脳水道辺縁及び第 4 脳室底に小出血及び微少出血を認め, 細胞病変 として, クロマトリーゼ, 腫脹, 空胞形成及び 核の移動，及び脳浮腫を認めると記載してい る.

本実験においては，出血は認めないが，血管 及び周囲の病変を認め, 組織の站啺化を認める ととから，間接的作用が衝いたと考える。しか しながら前述のように, 前庭系, 蝸牛系及び顔 面神経系の伝導路及び諸中枢化変化，即ち檤鞘 の変化, ニューロン及び周囲の変化及び神経線 維の変化，てれら諸変化と健常部が混在してい ることより，電気エネルギーによる間接的作用 あ考えられるが，さらに直接作用として，電気 化学的作用が神経伝導路並に諸中枢に働いたの ではないかと考える。

次にABRのI 波からV波は，聴神経より下 丘に至る蝸牛神経聴覚伝導路及び諸中枢に起因 する反応であろうと推測されている．I波は頭 皮上誘導の A B R 波形と局所の誘発電位の比較 の結果, 聴神経活動電位と報告されている。 同様に $\mathrm{IV} \cdot \mathrm{V}$ 波の局所誘発電位の比較検討 Sonnmer（1972）及び I C の破壊実験 ${ }^{39}$ の結 果，両側 I CはIV・V波に大きな関連があると いう。【波は，臨床報告 (聴神経腫禓等) 及び 蝸牛神経核の破垻実験の結果，蝸牛神経核に 大きな関連があると報告している，林波は，局 所誘発電位, 交又性聴覚路破坮及び一側内耳破 壊実験等の結果, 両側 S OCとくに反対側の
S O C K由来すると推測される，V波は，両側 I C 破壊，交又性珤覚路の切断， L L と S O C の破壊実験及び，I C 破壊実験の結果，同側の L L及び反対側のI C に関連すると推測され る、また V 波，V波にも，交又性が報告されて いる.

猫A B Rの各波潜時について，安藤 ${ }^{39}$ は I 波 潜時 $(1.45 \pm 0.09 \mathrm{msec})$, II 波潜時 $(2.35 \pm$ $0.12 \mathrm{msec})$ ， II 波潜侍 $(3.18 \pm 0.12 \mathrm{msec}), \mathbb{N}$ 波潜時 (4.38土0.16 msec)，及びV波潜時（6. $08 \pm 0.32 \mathrm{msec}$ ) を報告し, Bucnwald (1975) は，I波潜時 $(1.4+0.2 \mathrm{msec}) ，$ П波潜時（2.6 $\pm 0.3 \mathrm{msec}) ，$ III波潜時 $(3.5 \pm 0.4 \mathrm{msec}), \mathrm{IN}$ 波潜時 $(4.8 \pm 0.5 \mathrm{msec})$ ，及びV波潜時 $(6.7$ $\pm 0.7 \mathrm{msec}$ ）を報告している．本実験の測定值 は, I 波潜時 $(1.35 \pm 0.15 \mathrm{msec})$, II 波潜時 (2. $2 \pm 0.2 \mathrm{msec})$, III 波潜時 $(3.25 \pm 0.15 \mathrm{~m}$ $\mathrm{sec}), \mathrm{V}$ 波潜時 $(4.3 \pm 0.2 \mathrm{msec})$, 及びV波潜 洔 $(5.55 \pm 0.15 \mathrm{msec})$ であった。

10mA 20分間並に $2 \mathrm{~mA} \mathrm{20}$ 分間通電刺激した 結果, $10 \mathrm{~mA}$ 群においては右 I波加らV波及び 左非通電側 I 波からV波に変化を認め，その変 化量は，直後から 3 時間後に大であり，また左 右差を認める． $2 \mathrm{~mA}$ 群においては，右 I 波か らV波及び左 I からV波に変化を認め，その変 化量は， 2 から 3 時間後に大であり，10mA 群 と比較して, 反応が遅れ，また程度も軽い。

以上のととから， $10 \mathrm{~mA} 20$ 分間通電の結果, A B R.上では，相当部位は直後より何らかの影 響を受け 6 例中 2 例は直後より 3 時間後が最大 の変化であり，以後回復傾向を認め，一過性の 変化と推測する.一方， 6 例中 2 例は 24 時間後 に波形の消失，及び潜時の延長を認め，本実験 期間内では，A B R上，回復傾向は認めない変 化と推測する． $2 \mathrm{~mA} \mathrm{20}$ 分間通電の結果， A B $\mathrm{R}$ 上では，相当部位は， $10 \mathrm{~mA}$ 群に比較し，や や遅く反応し， 2 加ら 3 時間後に最大の変化を 認め，一過性のものと推測する。また通電によ り変化の出現する部位は, 同側の蝸牛神経, 蝸 牛神経核群近位， S O C， L L及び I C 並に反 


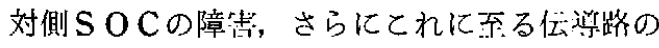
障㕩であることが推测される。

そして，南，小田，小幡及び、塚の報告で は, 側頭骨内内耳神経終末及び内耳神経組織の 陽性所見は，前庭系及び螪牛系はほぼ平行した 経時的変化を確認している．ABR上の所見及 び南らの報告より，通電刺激より24時間後まで の経時変化として，I波の経時変化にほほ平行 して, 前庭神経組織または, 前庭神経組織及び 前庭神経終末に同時に変化が起きているのでは ないかと推測する。な㧍本実験における病理組 織学的検索の成績, 即ちニューロン, 跹鞘, 血 管系及び支持組織の变化加らは, A B R 各波潜 時の短縮傾向を示したことの説明はつかない．

が, A B R 上各波の変化より推測した蝸牛神経 系上の障邫部位之 48 時間後の病理組織学的に陽 性所見を示す部位之は，ほほ一致する絬果之考 える.

以上，前庭神経伝尊路及び諸中枢の中にも陽 性所見を認めるとと, 直流電流が各神経伝採路 を流れた可能性, 及びA B R上の変化として， 当侅部に通電直後より変化のある可能性があ り, 通電刺激, unipolar test（側頭骨乳突部三 角一頭顶)，の主たる作用部伦として前庭系の うち, 未梢前庭系及び脳幹部とくに, 前庭神経 核群，MLF及びRF が今回の実験から考元ら れる。

臨床的飞通電刺激, 即ち Galvanic test, を 施行した成績中中枢関して，Bos and Jongkees $^{3)}$ は PENG を用い，電気性眼振の緩徐相 - 急速相が急速に変化しない事, 迷路性特発性 眼振のある症例に通電負荷する之笛気性眼振が 特発性眼振の緩徐相に superimpose すること， さらに温度眼振之電気性眼振を同時任負荷する 之電気性眼振が温度根振の緩徐相比 superimpose することより，非前庭系であると結論し た. Pfaltz ら ${ }^{18}$ は PENG 伦録を用い, reversal phenomenon を指整として, 栾床例 180 例 即ち, 脳幹下部, 橋部, 中脳及び皮質障害例を 検尌した。結果, 脳幹下部障害では一定した所
見はなく閥値、昇を認めるものがあること， 橋部障富では患側阿き galvanic nystagmus の 消失が起こる傾向にあること, 中脳障客では頻 度及び振幅の増加傾向があり抑制中枢の障害 が推測されること， C-P angle tumor では闒 值は正常であること, 及び皮質障害では閥值は 正常であるが Galvanic nystagmus 上障害側 向き galvanic DP を示すととを報告した，高 島 ${ }^{411}$ は PENG を用い, reversal phenomenon を指標として, (1)眼振解発閾值上昇, (2)眼振解 発抑制または廃絶, (3) galvanic DP, 及び (4) galvanic hyperexcitability 分類し, 脳幹部障 害で眼振解発抑制あるいは廃絶が起こる一方, 過敏反応, galvanic hyperexcitability, 屯起 るととを報告し，また著明な視運動性眼振の 抑制例浽視運動性眼振之同時に通電刺激 (2 $\mathrm{mA}$ )したところ, ほほ正常な視運動性眼振曲 線が得られたことより, 電気性眼振の発現機構 が所謂視運動性眼振反射回路之密接な関係を有 するあのであろうと推論した。

一方, 中島ら ${ }^{42}$ (1980) は A B R 成樍及び GBST を指標として，恥神経腪場例で GBST の閥值上昇を確認し, 前庭脊葡反射路の障害と 推測した. Tanaka ら ${ }^{9}$ は unipolar test を用 い Computed GBST を指標とし, C-P angle tumor 例に扔いて患側の無反応を報告した。

臨床の諸報告において, 通電刺激に用いる電 流量及び電極設置法は； (1) galvanic nystagmus 及び reversal phenomenon を指標とする場 合, Pfaltz $^{19}(0.1-10 \mathrm{~mA}$, bipolar $)$ 及び高泉 ${ }^{41}$ (0.1-10mA, bipolar), (2)galvanic nystagmus を指標とする梤合, Blonder ら ${ }^{43}$ (1937) (0.5$5 \mathrm{~mA}$, unipolar), Kayan $5^{44)}(0.5-2.5 \mathrm{~mA}$, bipolar), Young $\zeta(0-2 \mathrm{~mA}$, bipolar), Bos and Jongkees ${ }^{9}$ ( $2 \mathrm{~mA}$, bipolar), 時田 ${ }^{30}$ ) (18mA, bipolar), 及び福田ら ${ }^{45}$ ( (3mA, bipolar),

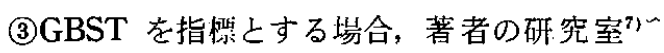
${ }^{17)}(0.6 \mathrm{~mA}$, unipolar 及び double galvanic), 中岛ら ${ }^{42}\left(0.5-2 \mathrm{~mA}\right.$, unipolar) 及び Coats ${ }^{46)}$ (0. 8mA, unipolar) である. 
これらの川で，中脳幥露における管気刺激 の反応態度の変化を報告しているのは，前述 Pfaltz 及び高舄である.同様に橋部障害にお ける変化を報告しているのは，Pfaltz，高島， 時田, Honjo, Tanaka ら及びゅ舅らである，高 島の橋部障害例で, galvanic hyperexcitability も起りうると報告したてと以外は，其通した所 見が得られている，以上のことから，橋部障 害, 即古 galvanic nystagmus $の$ 閥值上昇及 び GBST の闒值上昇は，指鄁，電極設置法， 及び通電電流量にょらず診断し得ると推測す る。また中脳に関しては， GBST に比較して 大きな電流量を用いる galvanic nystagmusを 指憋とする方が，諸報告からは優利かと考えら れる。

一力，前庭神経核とくに比加ら R Fへの投 射路があり前庭系と密接な関係があるとと， $\mathrm{R}$ Fの大部分の埸㠼は促進的に㗢くこと，高跗が 電気性眼振闘值下 ( $2 \mathrm{~mA})$ 刺激を温度昨振検 查及び視連動性眼振検查に同時会荷した綃果， 前庭性眼振抑制例の著明な賦活を悡めたこと， 及び本実験の $2 \mathrm{~m} \mathrm{~A} 20$ 分間通電刺激において,

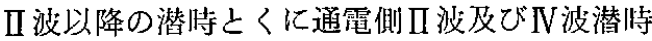
の有意の延長傾向を認め，橋レベルあるいは橋 レベルから下不レベルの閒には，通電刺激の作 用が及九でいると推測されること（但しネンブ

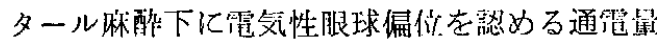

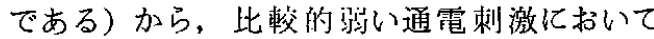
屯，橋レベルあるいはさらに上位の障害部估診 断に役立つ可能性がある。また $10 \mathrm{~mA}$ 群におい て前庭神経核群，MLF及びR F に陽性所兒を 認めるとと，直流電流が神経伝等路を経由する ことが推測されるとと及びR F から脊葡に対し て網椂体脊䯑路を介して抑制と促進の両方の影 響を与える る荡合と同様 GBST を指缃とする場合にも中 枢前庭系病変の局在㟝断が可能ではないかと 考える。乙の場合，報告中，脳幹部障害例に ついて述べられていないが，朴沢の ${ }^{33)}$ Galvanogram, 関谷の Galvanogram が役站つと考元 る.

本実験で使用した刺激電流の種類は，時田ら によれば，平流電流，急速通電によるものに相 当するが，迷路に通電した場合，電気の刺激作 用による反吣と電気の緊張作用による反応があ るという ${ }^{30)}$. また鈴木 ${ }^{48}(1967)$ は，平流刺激 とパルス刺激の相垶を報告している。

今後, 迷路 (侧頭部) に通電をする場含, 刺 激電流の種類，雷極設置法及び指棷の検討，ま た同時負荷等を考慮すれば，監休応用として脳 翰部障害の診断に更に役立つと考える。

\section{桔}

本研究は，耳後部通電後の前庭神経系並に蝸牛神経系の变化，特に被刺激部位局在性について榆 洏するととを目的とした，指愊は，電気性眼球偏位，A B R及び病理組織学的検索である．神経耳 科的にみて健康なる猫を用い，ネンブタール森酔下に側頭等乳突部三角（陰極）一頭頂（陽極）間 通電実験を行った，通霍波帅は矩形波とし，通電時間は全て20分である．電気性眼球偏位は通電印 並に通電後24時間にわたり経侍啲に維察したＡＢＲの計测は，潜時，波形及び波高について，通 電前並に通電後 24 時間まで経時的に行った，病理組織学的検索は，通電48時間後に生体環流固定を 行い，主として脳幹部並に陽電極直下の大脳より標本を作製し，各種神経染色を行い，光顕的に镇 察した，成績は次の通りである。

1 ）通電刺激時, $10 \mathrm{~mA}$ 群及び $2 \mathrm{~mA}$ 群全例に電気性眼球偏们を認めた.

2）通電時, 短時間小さく通電側への眼球偏位を認めた。

3）A B R 所胃上， $10 \mathrm{~mA}$ A群一対照群間の群間比較に执いて，右 I 波・III波及びV波潜時並に左 （非通電側）I 波及びV 波潜侍に有意な差を認める（ $\mathrm{P}<0.05$ 及び $\mathrm{P}<0.01 ）$ ．同様に $2 \mathrm{~mA}$ 群一対 
照群間の群間比較において，左右とあI波からV波潜時に有意な差を認める，（ $\mathrm{P}<0.05$ 及び $\mathrm{P}<$ 0.01 ).

4) $10 \mathrm{~mA}$ 群では，波形の消失は，右川波から V波及び左（非通電側）【波・II波及びV波に認 める。 $2 \mathrm{~mA}$ 群では, 左右 V波に認める.

5) $10 \mathrm{~mA}$ 群の変化は, 左V波を除き， $2 \mathrm{~mA}$ 群に比較して大であり，測定归間内非可逆性の変 化も認める. $2 \mathrm{~mA}$ 群の変化は一過性と考える.

6) $10 \mathrm{~mA}$ 群では, 病理組織学的検索にて, 右側の前庭神経核群, 蝸牛神経核群, 外側毛寡, 顔 面神経核, 外転神経核, 顔面神経, 及び左右の脳幹網媒体, 内側縦束, 上オリーブ核, 中心灰白質, 下丘及び下丘交連に陽性所見を認める。 $2 \mathrm{~mA}$ 群は 6 例中 1 例に陽性所見を認める.

7 ) 本実験の通電刺激の作用部位として，末梢前庭系及び脳幹部とくに，前庭神経核群，内側縦 束及び畄幹網様体が考えられる。

稿を終るにあたり，終始，䅰切なる御指導と御校閲を戴いた恩師関谷透教授に深甚なる謝意を表します：また 研究に際し適時御助言を頂いた，第一解剖学教室粟屋和彦教授，友永進助教授，精神神経科学教室山田通夫教授 並に御協力を頂きました耳悬咽喉科学教室各位に深く感謝いたします. 本論文の要旨は，第 8 回日耳鼻中国地方 部会 (1982, 広島), 第30回日本基礎耳科学会 (1983, 大阪) 及び第84回日本耳兽咽喉科学会総会 (1983, 大阪) において発表した。

1) 石原亮：前庭器の電気刺激に因て起る家鬼の眼反 応汇就て，福岡医誌 13:420 464，1920。

2) Swaak, A. J. G. and Oosterveld, W. J. : The effect of galvanic stimulation on spontaneous nystagmus. Oto-Rhino-Laryngol $38: 140 \sim$ 147, 1976.

3) Bos, J.H. and Jongkees, L.B.W. : On galvanic stimulation of the labyrinth. Pract Otorhino-laryngol $25: 345 \sim 348,1963$.

4) 增田周：Galvanic test の研究. 耳鼻臨床 53 : 1507 1529, 1960.

5 ) 関谷透: Galvanic test の研究——加速度記録図 法による電気性頭部動摇の観察と Galvanogram の表現—． $68 ： 996 \sim 1015 ， 1965$.

6）松本圭倨：Galvanic test $の$ 踟床的研究一一直立 位における身体動㨟について一。. 耳鼻臨床 63 : 1013 1027, 1970.

7) 田中宗昭, 他 : Medical Computer による Galvano-ARG の検討. Equilibrium Res 32 : 67〜69, 1973.

8) 田中宗昭, 他： Medical Computer による Galvano-ARG の検討. Equilibrium Res 33 : 68 72, 1974.
文献

9) Tanaka, M., et al. : Clinical significance of Galvanic Body-Sway. Bull. Yamaguchi Med School $22: 495 \sim 507,1675$.

10) Tanaka, M. : Investigation of Galvanic test --Analysis of Galvanic Body-Sway using with medical data processing computerBull. Yamaguchi Med School 21:61 79, 1974.

11) Sekitani, T.: Vestibular neuroitis. Bull. Yamaguchi Med School $22: 317 \sim 324,1975$.

12) Sekitani, T. and Tanakà, M. : Test for galvanic vestibular responses----Survey through our experimental and clinical investigations for last 20 years_- Bull. Yamaguchi Med School $22:$ 439 452, 1975.

13) Sekitani, T. : Vestibular neuritis. Bull Yamaguchi Med School 22: 317 324, 1975.

14) Okuzono, T., et al.: Computed Galvanic BodySway Test - Peculiarity in vestibular neuronitis_- Postual Reflex and Body Equilibrium $2: 97 \sim 105,1981$.

15) Honjo, S., et al. : Body-Sway induced by galvanic stimulation. Agressiologie (Paris) 
$17: 77 \sim 84,1976$.

16) Honjo, S., et al. : Galvanic body-sway test for the differential diagnosis of vertigo. Vestibular Mechanisms in Health and Disease 342 348, Academic Press, London 1978.

17) 田中宗昭, 他：CP症例に拈ける Galvanic Body-Sway Test の有用性について. Equilibri一 um Res $37:$ 164 165, 1978.

18) Pfaltz, C.R.P., et al. : Galvanic test in central vestibular lesions. Acta Otolaryngol (Stockh) $65: 161 \sim 168,1968$.

19）北原正章, 他：Galvanic test. 厚生省特定疾患 前庭機能異常調查研究班昭和57年度研究報告彗 p. 42 46, 1983.

20) Bossy, J.: Atlas of neuroanatomy and special sense organs. W. B. Saunders Co. Philadelphia, 1970.

21) Thompson, G. : Structure and function of the central auditory system, Seminars in Hearing $4: 81 \sim 95,1983$.

22) 南德次：電気刺激に因る聴器障害の実験的研究一 聴器の病理組䑮学的研究一. 耳㑭臨床 $24: 165 \sim$ $177,1930$.

23）南徳次：電気刺激に因る聴器障害の実験的研究一 聴神経中枢䅅路に於ける病変に就て一，耳鼻臨床 $24: 178 \sim 183,1930$.

24）小田大吉：電気的刺激に因る聴器病理. 大日耳鼻 $33: 409 \sim 411,1927$.

25）小田大吉：電気的刺激に因る聴器病理. 大日耳鼻 $34: 1147 \sim 1149,1928$.

26）小田大吉 : 電気的刺激に因る聴器病理第（3 回報 告). 大日耳鼻 $35: 171 \sim 173,1929$.

27) 小幡達男：電気刺激に因る德器病変の実験的研究 (前篇). 日耳恖 $56: 619 \sim 625,1953$.

28）小幡達男：電気刺激に因る聴器病変の実験的研究 (後篇). 日耳亩 $56: 626 \sim 630,1953$.

29）上塚萬壽男：電気災害に园る聴器病変の実験的研 究. 岡山医誌 $73: 731 \sim 748,1966$.

30) 時田喬, 他：電気眼振検查法の検討, 耳鼻臨休 $60: 38 \sim 57,1967$.

31) 南德次：電気刺激に因乃聴器障害の奏験的研究 （II）一剌激後に発来する特発眼球震燙の発現部 位に就いて一。耳鼻臨床 $24: 44 \sim 57,1930$.
32）吉野幸雄, 他：電気性眼振に関する実験的研究. 日耳鼻 $73: 429 \sim 472,1970$.

33）朴沢二郎：電気性眼振の発現機構について. 耳賞 臨床 $60: 90 \sim 94,1967$.

34) Lowenstein, $O$. : The effect of galvanic polarization on the impulse discharge from sense endings in the isolated labyrinth of the thornback ray. J Physiol $127: 104 \sim 117$, 1955.

35) 石川正：内耳性筋反応に関する研究——筋電欧に よる迷路性筋緊張——. 日耳鼻 $61 ： 1035 \sim 1045$ ， 1958.

36) 石川正：迷路直流通電刺激による筋反忍一一内耳

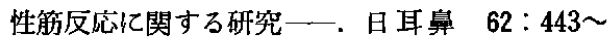
462, 1956.

37）青木茂：反覆頭部通電による迷路反射の変化. 日 耳鼻 $63: 765 \sim 777,1960$.

38) Peters, G. (挾閏章忠, 他訳)：臨床神経病理学, 第 9 章物理的要因による中枢神経系, 第45節電気 的エネルギーの作用による病変, 病理解剖学的変 化 p. 477 484, 医函薬出版, 東京, 1976 .

39）安藤一郎：B S Rの実験的研究一下丘破壊による B S Rの変化一. Audiology Japan 20:210 $220,1977$.

40) 黄田正忠, 他：㯖性脳幹反忍における単耳刺激と 両耳刺激一一動物実験的考察—. A Adiology Japan 23:195 172, 1980.

41) 高島三喜 : 電気性眼振検查の臨床的研究—P E NG記録による梌討一。昁鼻 $74: 77 \sim 92$, 1971.

42）中島成人，他：Galvanic Sway の刺激部位につ いて一一蛤電図検査成績との比較よりみた一考察 —_. Equilibrium Res $39: 29 \sim 33,1980$.

43) Blonder, E. J., et al. : The galvanic falling reaction in patients with verified intracranial neoplasms. JAMA $107: 411 \sim 412,1936$.

44) Kayan, A., et al. : The use of galvanic vestibular nystagmus in clinical otology. J Laryngol 503 513, 1974.

45）福田精, 他：Galvanic test の一規準。日耳鼻 $65: 279,1962$.

46) Coats, A.C. : Effect of varying stimulus parameters on the galvanic Body-sway res- 
ponse. Ann Otol Rhinol Laryngol 82: 96 102, 1973.

47）関谷透：前庭神経系の伝導路とその中枢結合. め まい一一基礎と臨床一一, 本庶正一, 原田康夫, 関谷透共著, P. 67 89, 金原出版, 東京, 1976 .
48）鈴木淳一：電気性迷路反射. 耳鼻臨床 $60 ： 83$ 89, 1967.

原稿到着：昭和59年 2 月 13 日 別刷請求先：日吉正明

T755 山口県宇部市小串1144

山口大学医学部耳鼻咽喉科学教室 